\title{
Recent Insights Into Processing Approaches and Potential Health Benefits of Goat Milk and Its Products: A Review
}

OPEN ACCESS

Edited by:

A. M. Abd El-Aty,

Cairo University, Egypt

Reviewed by:

Emel Oz,

Atatürk University, Turkey

Ahmed A. Zaky

National Research Centre, Egypt

Ignacio Vieitez,

Universidad de la República, Uruguay

${ }^{*}$ Correspondence: Daniel Severus Dezmirean ddezmirean@usamvcluj.ro

Gulzar Ahmad Nayik

gulzarnaik@gmail.com

Specialty section:

This article was submitted to

Food Chemistry

a section of the journal

Frontiers in Nutrition

Received: 04 October 2021 Accepted: 10 November 2021 Published: 06 December 2021

Citation:

Nayik GA, Jagdale YD, Gaikwad SA, Devkatte AN, Dar AH, Dezmirean DS, Bobis O, Raniha MMAN, Ansari MJ, Hemeg HA and Alotaibi SS (2021) Recent Insights Into Processing Approaches and Potential Health Benefits of Goat Milk and Its Products:

A Review. Front. Nutr. 8:789117. doi: 10.3389/fnut.2021.789117

\begin{abstract}
Gulzar Ahmad Nayik ${ }^{1 *}$, Yash D. Jagdale², Sailee A. Gaikwad ${ }^{2}$, Anupama N. Devkatte' ${ }^{2}$, Aamir Hussain Dar ${ }^{3}$, Daniel Severus Dezmirean ${ }^{4 *}$, Otilia Bobis ${ }^{4}$, Muhammad Modassar A. N. Ranjha ${ }^{5}$, Mohammad Javed Ansari ${ }^{6}$, Hassan A. Hemeg ${ }^{7}$ and Saqer S. Alotaibi ${ }^{8}$

${ }^{1}$ Department of Food Science \& Technology, Government Degree College Shopian, Jammu and Kashmir, India, ${ }^{2}$ Maharashtra Institute of Technology (MIT) School of Food Technology, Art, Design and Technology University, Pune, India, ${ }^{3}$ Department of Food Technology, Islamic University of Science \& Technology, Awantipora, India, ${ }^{4}$ Department of Technological Sciences, Faculty of Animal Science and Biotechnology, University of Agricultural Sciences and Veterinary Medicine Cluj-Napoca, Cluj-Napoca, Romania, ${ }^{5}$ Institute of Food Science and Nutrition, University of Sargodha, Sargodha, Pakistan, ${ }^{6}$ Department of Botany, Hindu College Moradabad (Mahatma Jyotiba Phule Rohilkhand University Bareilly), Moradabad, India, ' Department of Medical Laboratory Technology, College of Applied Medical Sciences, Taibah University, Medina, Saudi Arabia, ${ }^{8}$ Department of Biotechnology, College of Science, Taif University, Ta'if, Saudi Arabia
\end{abstract}

Goat milk is considered to be a potential source of various macro- and micro-nutrients. It contains a good proportion of protein, fat, carbohydrates, and other nutritional components which help in promoting nutritional and desirable health benefits. Goat milk is considered to be superior in terms of numerous health benefits, and lower risk of allergy, when compared to the milk of other species. Several processing techniques such as pasteurization, ultrafiltration, microfiltration, and ultrasound have been employed to enhance the quality and shelf life of goat milk and its products. The diverse range of goat milk-based products such as yogurt, cheese, fermented milk, goat milk powder, and others are available in the market and are prepared by the intervention of advanced processing technologies. Goats raised in pasture-based feeding systems are shown to have a better milk nutritional composition than its counterpart. Goat milk contains potential bioactive components, which aids in the maintenance of the proper metabolism and functioning of the human body. This review gives insight into the key nutritional ingredients and bioactive constituents present in goat milk and their potential role in the development of various functional foods using different processing technologies. Goat milk could be considered as a significant option for milk consumption in infants, as compared to other milk available.

Keywords: goat milk, pasturized milk, health benefits, processing, milk products

\section{INTRODUCTION}

The goat has been known as the oldest domesticated animal in mankind's history as a source of milk and different dairy products, required for survival as well as fulfilling the need for a nutritious and balanced diet. Although goats only contribute around 2\% production supply of the world's total milk, their significance in the economic upliftment and nutritional well-being of 
the human population is crucial in several regions around the world, particularly in the Middle East and Mediterranean countries (1). Goats have been categorized into a variety of breeds and are raised in different environments across the world. The goat breeds specifically meant for milk production and dairy products are receiving more focus on a study regarding milk quality and its yield (2). Many recent international and national conferences proceedings have highlighted and demonstrated the relevance of goats as global producers of vital food in the form of meat and dairy products (3). There are $\sim 1$ billion goats on the planet, and the global goat population has doubled over the last four decades. According to the Food and Agriculture Organization (FAO), developing countries are home to more than $90 \%$ of the world's goat population; Asia has the largest proportion of the world's goat population, followed by Africa (4). Goat is considered to be valuable to local farmers for both economic and subsistence reasons, by contributing to the enhancement of the livelihood of marginal farmers (5). The global output of goat milk is projected to be $\sim 15,500,000$ tons per year, with the developing nations accounting for 83 percent of the total (6).

Currently, non-bovine annual milk production stands at 133 million tons, representing more than $17 \%$ of total milk output worldwide. Goat milk production represents $13.5 \%$ of the total output of non-bovine milk, making it the most significant contributor (7). Goat milk is generally consumed directly or used to make a diverse range of dairy products, and it is estimated that a large population consumes goat milk and its products across the world $(8,9)$. Because a large portion of domestic non-commercial consumption and production remains unrecorded, the goat milk yield is likely to be considerably greater than what these official figures suggest (10). Due to the natural reproductive cycles, the availability of food during the rainy season, and leftover feed from seasonal harvest, there is yearly fluctuation in goat milk, production and is seasonal (11). Consumption of goat milk like that of other ruminant species is impacted by different factors involving individual features, breed, handling, stage of lactation, the composition of feed, climate, and vast differences not only across but also within the system of production $(12,13)$. Studies concluded that it is possible to modify the fatty acid composition of ruminant products by manipulating their diet with appropriate dietary fat sources. An interesting characteristic of goats is the fact that they are more resistant than cows to milk fat depression after fat addition to the diet $(14,15)$.

Goat milk is a great dietary source. It provides ample benefits for the health maintenance, physiological process, and in the nutrition of younger and the elderly population, and some studies have reported that it may be consumed by most of the population susceptible to cow milk allergy (16). Due to its nonallergic nature, digestibility, and contribution to the reduction of poverty and hunger at the community level in local producers and the ultimate consumer, the positioning of goat milk, should be on a global level (10). In terms of unique alkalinity, greater buffering capacity, and therapeutic potential in human nutrition and medicine, Goat milk varies from human milk or cow milk (3). Without the interventions of sanitary processes, and suitable manufacturing techniques specialized products derived from goat milk cannot be manufactured. However, issues about control of sanitation and the necessity to implement standards and quality tests remain a persistent problem for the marketing of goat milk and its products. A better incentive is payment based on the product quality, both in terms of microbiological condition (count of somatic cell and bacteria) and nutritional content (fat and protein) (17). It has long been recognized that goat milk naturally has a higher concentration of somatic cells than cow milk, owing to the mammary gland's apocrine secretory mechanism (18). A high somatic cell count (SCC) has a significant impact on the quality of goat milk. A study demonstrated that alterations in milk quality associated with SCC $>600.103 / \mathrm{mL}$ (5.58 LSCS) in a farm with extremely strict sanitation standards and no detectable mastitis-causing bacteria (MCB) in the mammary gland. The findings indicated that even a lower value of SSC can have a substantial effect on goat milk's technological features. The routine screening of SSC should be exhibited and reported to dairy manufacturers to ensure the consumer receives a high-quality end product (19).

The current trend toward the demand for healthy foods and in developed nations has developed in interest in goat milk and its products (1). Goat milk contains in abundance protein, fatty acids, and minerals (20). The excellent digestibility and nutritional content of goat milk, as well as its therapeutic potential, make it an important functional food (7). These characteristics pave way for the manufacturing of a wide range of dairy products from goat milk, including yogurt, cheese, nonfermented and fermented beverages, condensed milk, butter, ice cream, and sweets (21). This review generally focuses on the nutritional profile of goat milk, different preservation techniques in enhancing the quality and storage of goat milk, application of different processing technologies in the manufacturing of a wide range of goat milk-based products, and the potential health benefits of goat milk in human health and nutrition.

\section{COMPARISON OF GOAT MILK}

\section{Comparison of Goat's Milk-Based on Pasture-Based and Indoor-Based Feeding System}

Consumption of grass at the initial stage of growth positively influences the production of goat milk and its fat content. The modification of milk quality and its composition is largely dependent upon the variety of fodder species, stage of vegetation, stocking rate, and season. Pasture-based natural farming techniques generate milk that is high in fat and micronutrients (fatty acids, vitamins), as well as volatile components (flavor, terpenes). The comparison of three systems of feeding derived from natural pasture on the mountains, hills, and in the plains suggests that on the mountain pasture, the milk yield is rather lower but the content of protein, fat, and PUFA percentage are relatively higher (Table 1). The higher content of conjugated linoleic acid in milk is observed when the feed of grass obtained from natural pasture is given at an early stage. In intensive types of indoor systems, a high intake of fodders with high nutritional value or a plentiful supply of concentrates enables the production 
TABLE 1 | Comparison of fatty acid composition of goat milk based on pasture-based and indoor based feeding system.

\begin{tabular}{|c|c|c|c|c|}
\hline \multirow[t]{2}{*}{ Fatty acid } & \multicolumn{4}{|c|}{ Feeding based system } \\
\hline & $\begin{array}{l}\text { Indoor-Based (Hay) (mg } \\
100 \mathrm{~g}^{-1} \text { dry matter) }\end{array}$ & $\begin{array}{l}\text { Pastured-Based (mg } 100 \\
\mathrm{~g}^{-1} \text { dry matter) }\end{array}$ & $\begin{array}{c}\text { Indoor-based (Hay and } \\
\text { concentrate) (mean } \pm \text { SD), \% of } \\
\text { total FA }\end{array}$ & $\begin{array}{l}\text { Pastured-based (mean } \pm \\
\text { SD), } \% \text { of total FA }\end{array}$ \\
\hline$\alpha$-linolenic acid & 354.6 & $1,507.3 \pm 395.34$ & $0.71 \pm 0.08$ & $0.71 \pm 0.13$ \\
\hline Saturated fatty acids & 446.8 & $445.7 \pm 32.72$ & $69.12 \pm 1.91$ & $70.85 \pm 3.59$ \\
\hline Monounsaturated fatty acids & 109.8 & $112.5 \pm 8.56$ & $26.85 \pm 1.80$ & $25.16 \pm 3.28$ \\
\hline Polyunsaturated fatty acids & 543.1 & $1,857.4 \pm 459.35$ & $4.04 \pm 0.19$ & $4.00 \pm 0.50$ \\
\hline Total fatty acids & $1,099.7$ & $2,415.6 \pm 492.04$ & - & - \\
\hline
\end{tabular}

of milk that is high in protein and low in fat. The feeding of a lower-fat or fiber diet to goats can help in reversing the fat to protein ratio percentage, especially during mid-lactation. As a result, the lowering of cheese quality in terms of good taste and granular paste is observed. The increase of concentrate supply to $60 \%$ of total intake of dry matter in diet can result in a slow and linear decline of fat content, but when the intake concentration approaches $60-80 \%$, there is a rapid decline in the fat content due to greater shortage of fibrosity in the ration (24).

The proportion of diet concentrate has a relative effect on the amount of iso-C15:0, iso-C16:0, and C13:0 in goat fat milk. Comparing conventional and organic farming systems with grazing and a smaller fraction of conserved forage often reveals a greater proportion of nutritionally beneficial fatty acids such as PUFA n3, branched fatty acids, and rumenic acid (25). In a study, the diet of Alpine goats was supplemented with hempseed or linseed, and later, the milk was analyzed after 14 weeks of treatment. The results demonstrated that feeding a seed enriched diet positively influenced the composition of fatty acids with an elevation in unsaturated fatty acids. Linolenic acid content was significantly increased in the linseed diet compared to the hempseed and the control diet. However, linoleic acid content was significantly elevated solely with hempseed supplementation. A variety of conjugated linoleic acid (CLA) isomers and greater levels of trans-configuration fatty acids were identified in supplemented diets, notably in the linseed diet (26).

\section{Comparison of Goat Milk With Cow Milk}

Triglycerides are the primary components of milk fat, accounting for $97-98 \%$ of total milk lipids. The triglycerides composition of bovine milk fat is extremely complicated, containing around 1,300 distinct potential triglycerides if only the triglycerides whose content is above $1 \%$ are taken into account. Numerous studies indicate that dependence of availability of grass (which fluctuates seasonally), and supplementation with seeds such as soy meal, canola, or rapeseed can significantly enhance the CLA concentration of milk up to 50 percent. As a result, significant differences in the CLA content of goat and cow milk from different nations are to be expected $(27,28)$. There is extensive
TABLE 2 | Comparison of different triglycerides content of goat milk and cow milk.

\begin{tabular}{lccccc}
\hline & \multicolumn{2}{c}{ Vieitez et al. (27) } & & \multicolumn{2}{c}{ Gastaldi et al. (28) } \\
\cline { 2 - 3 } \cline { 5 - 6 } & $\begin{array}{c}\text { Goat milk } \\
\text { (wt\%) }\end{array}$ & $\begin{array}{c}\text { Cow milk } \\
\text { (wt\%) }\end{array}$ & & $\begin{array}{c}\text { Goat milk [mol\% } \\
\text { (mean value } \pm \text { SD) }\end{array}$ & $\begin{array}{c}\text { Cow milk [mol\% } \\
\text { (mean value } \pm \text { SD)] }\end{array}$ \\
\hline C4:0 & 2.4 & 4.2 & & $5.07 \pm 0.023$ & $8.45 \pm 0.024$ \\
C6:0 & 2.8 & 2.6 & & $3.78 \pm 0.018$ & $3.93 \pm 0.018$ \\
C8:0 & 3.3 & 1.4 & & $3.03 \pm 0.029$ & $2.08 \pm 0.015$ \\
C10:0 & 11.5 & 2.8 & & $17.2 \pm 2.17$ & $2.89 \pm 0.38$ \\
C12:0 & 4.6 & 3.1 & & $6.18 \pm 0.093$ & $3.21 \pm 0.053$ \\
C14:0 & 10.0 & 11.2 & & $12.9 \pm 0.86$ & $11.7 \pm 0.78$ \\
C16:0 & 25.7 & 29.3 & & $21.1 \pm 0.33$ & $21.9 \pm 0.338$ \\
C18:0 & 9.7 & 9.9 & & $8.11 \pm 0.659$ & $12.9 \pm 1.06$ \\
\hline
\end{tabular}

evidence indicating that the fat composition of goat and cow milk is significantly different. As a result, the composition of lipids from products derived from these milk types, such as cheese, will vary (29-32). The difference in triglycerides content of goat and cow milk is given in Table 2 .

\section{PROCESSING OF GOAT MILK AND ITS PRODUCTS}

The fundamental processing techniques involved in the processing of fluid goat milk are similar to that of cow milk. Receiving milk, filtering, standardizing, pasteurizing, chilling, packing, storing, and distributing fluid goat milk are the key processes and techniques used. However, goat milk is commonly not required to be homogenized attributed to the prevalence of smaller fat globules than cow milk, resulting in a naturally homogenized consistency. After the milk is collected from an individual animal, a bulk tank, or a milk transportation truck, it is filtered to remove unwanted elements like sediments, udder body cells, and certain bacteria (33). Clarification is used in the removal of excess impurities through distributing the milk into thin layers over conical disks, revolving at a relatively high speed. Bactofuge, a unique machine that operates at considerably 
higher centrifugal force, has been developed for a high degree of bacterial decontamination (34). Depending upon the time and temperature relation, pasteurization can be performed asLow-temperature long time $\left(65^{\circ} \mathrm{C}, 30 \mathrm{~min}\right)$; high-temperature short time $\left(72-75^{\circ} \mathrm{C}\right.$ for $\left.25 \mathrm{~s}\right)$; Ultra-high temperature (125 \pm $5^{\circ} \mathrm{C}$ for $4 \mathrm{~s}$ or $\left.135 \pm 5^{\circ} \mathrm{C}, 4 \mathrm{~s}\right)(35-37)$. Pasteurization is critical to avoiding human brucellosis (multiple organ disease), which is frequently transmitted via unpasteurized goat milk and its cheese (38).

Following pasteurization, and chilling of the milk, it is bottled or packaged in paper or plastic cartons or other forms of packaging. This processed and packaged fluid milk is subsequently distributed to retail and other marketing outlets in refrigerated vans. The process of separation of cream in goat milk is optional, as goat milk cream is rarely found in commercial markets (33). The primary objective of cream separation is to standardize milk fat and produce butter, ice cream, and other dairy products. The cream is produced by the process of separation of skim milk from whole milk, resulting in the formation of fat-in-water emulsion enhanced with milk fat that has been heat-treated according to industry standards (39).

\section{Processing of Goat Milk Cheese}

The first step in cheese making is obtaining high quality goat milk that is free from visible impurities, abnormal odor or taste, foreign substances, pathogenic microorganisms, and should possess desirable acidity ( $\mathrm{pH}$ 6.2-6.55). Also, the cheese starter culture bacteria must survive and multiply after being added to the milk (40). The typical farmhouse goat milk cheese making process consists of the nine fundamental stages listed below (41): milk filtering $\rightarrow$ renneting $\rightarrow$ milk coagulation $\rightarrow$ putting the curds into appropriate cheese molds $\rightarrow$ draining $\rightarrow$ unmoulding $\rightarrow$ salting $\rightarrow$ drying $\rightarrow$ ripening (42). Although the core cheese making methods are identical in many goat cheeseproducing nations, several distinct kinds of caprine cheeses may be created due to variations in the milk content, changes in the production procedures, and a wide range of maturing time and circumstances. The major types of cheese are $(33,43,44)$ :

\section{Soft Goat Milk Cheese}

Several thermophilic and mesophilic microorganisms or their combination, that is, Lactococcus Lactis subsp. Lactis, Lactococcus Lactis subsp. cremoris, and Streptococcus thermophilus as well as mesophilic ones including Lactococcus Lactis subsp. lactis and Lactococcus Lactis subsp. cremoris are commonly utilized starter cultures for soft goat milk cheese (45). Goat milk is pasteurized for $120 \mathrm{~min}$ at $62.8^{\circ} \mathrm{C}$, followed by gradual coagulation and natural draining, and then wrapping in cheesecloth, subsequent hanging for 3 days in a cold environment $\left(22^{\circ} \mathrm{C}\right)$ before packing. Polyolefin shrink wrap is used for the packaging of this type of cheese.

\section{Semi-hard and Hard Cheese}

The pasteurization of goat milk is exhibited at $62.8^{\circ} \mathrm{C}$ for $30 \mathrm{~min}$. IFPL starter culture [contains the adjunct Lactobacillus casei subsp. casei (IFPL731) and isolated Lactococcus lactis subsp. lactis (IFPL359), Lactobacillus plantarum (IFPL935),
Leuconostoc paramesenteroides (IFPL705), and Leuconostoc mesenteroides subsp. dextranicum (IFPL709)], homofermentative starter culture (EZAL ${ }^{\circledR} \mathrm{MA011}$, which contains Lactococcus lactis subsp. cremoris and Lactococcus lactis subsp. lactis) (46), Lactococcus lactis subsp. lactis LPS31 strains, Lactobacillus casei subsp. casei 3PS103, and Streptococcus thermophilus SPS1 (47), etc., are different starter cultures usually utilized for semi-hard and hard cheese. In addition to starting culture, single strength rennet in milk and then allowing it to coagulate. Cutting of curd and allowing it to heal for $5 \mathrm{~min}$. The temperature is progressively increased to $39^{\circ} \mathrm{C}$ over $30 \mathrm{~min}$ and then cooking of curds until it becomes firm for 45-60 min. After draining two-thirds of the whey $\left(31^{\circ} \mathrm{C}\right)$ warm water is poured into the vat for washing of curd and to bring the whey temperature at $\left(31^{\circ} \mathrm{C}\right)$. Before the whey is entirely drained, the curds are steeped in water for $5 \mathrm{~min}$. The curds are then pressed in vertical cheese press at $40 \mathrm{psi}$ overnight for room temperature. The cheese is then taken from the molds, sliced into discs, vacuum-packed in plastic pouches using a vacuum packaging, and then stored at $4^{\circ} \mathrm{C}$.

\section{Blue-Veined Cheese}

Roquefort and Savoy generally manufactured in France and Cabrale found in Spain are some of the popular Blue-veined cheese. The blue cheese curd is made with rennet and lactic acid culture. After curdling for $1-2 \mathrm{~h}$ and inoculation with penicillium, it displays the appearance of a bluish or greenish marble. After piercing and salting, the ripening of cheese is exhibited for a period of 1-4 months at a temperature of $9-10^{\circ} \mathrm{C}$ and relative humidity of $90-95 \%$ (48).

\section{Acid-Coagulated Cheese}

Crottin de Chavignol PDO, like the majority of cheese produced from French goat raw milk, is an acid-coagulated type of cheese. Milk is usually procured from Alpine goats. The culturing of commercial starters should be done from the delimited area of goat milk before being inoculated in vat milk. Frozen or fresh whey can also be utilized as a source of starter culture from previous cheesemaking and a minimum of two starter strains must be inoculated. After the process of pre-draining, frozen curd can be combined with fresh curd to achieve a ratio of frozen to fresh curd of 1:1. The time for transportation of cheese to the maturation plant and storing it before salting should not exceed $72 \mathrm{~h}$, and it should be kept at a temperature lower than $10^{\circ} \mathrm{C}$. The minimum period required for the maturation of cheese is 10 days to a maximum of 15 weeks. After the usual maturation, Chavignol "repasses" must be matured in the absence of airflow (49).

Apart from basic cheese manufacturing procedures, advanced techniques such as ultrafiltration can be utilized in enhancing the quality and yield of goat milk cheese. For the manufacture of retentate, considered as a fraction of pre-cheese from goat milk, ultrafiltration was utilized. The portion was then processed into cheese. Due to the maintenance of whey proteins with the curd and utilization of lower rennet, the rate of cheese production increased by 8 to $15 \%(50,51)$. It is now feasible to make goat milk cheese with ultrafiltration technology even when there is a lack of fluid milk supply. The ultrafiltration method also offers benefits for the manufacturing of a cream cheese-type product, such that 
the pre-cheese material can be held for relatively more time in frozen storage for future use (50). The major obstacles to the manufacturing of goat milk cheese are a lack of $\alpha \mathrm{S} 1$-casein, high somatic cell numbers, rancid flavor, and a greater concentration of free fatty acids (52).

\section{Processing of Goat Milk Yogurt}

Goat milk yogurt products based on production technology are classified as below $(33,53)$ :

(a) Set-type yogurt consisting of a firm gel that is the result of incubating milk with a starting culture in the final packaging.

(b) Stirred-type yogurt, having a relatively decreased firm texture than set-type yogurt. In this example, the coagulum is broken, agitated, and packed while incubating in a tank.

(c) Yogurt that has been strained or concentrated to have a creamier texture and a less acidic flavor. It can be made from stirred yogurt that has been concentrated by utilizing a cloth bag, ultrafiltration, or mechanical separation.

(d) Yogurt involving total solids of around $\sim 26 / 100 \mathrm{~g}$, comparable to a typical product, or made from recombined dairy components such as various milk powder and anhydrous milk fat, salt (optional), and stabilizer.

In an experiment performed by Jia et al. (54), the following process was utilized for the preparation of goat milk yogurt by using Lactobacillus rhamnosus GG. Firstly, skim milk sterilization was performed at $105^{\circ} \mathrm{C}$ [solids concentration of $11 \%(\mathrm{wt} / \mathrm{wt}$ )] for activation of strain. L. delbrueckii ssp. bulgaricus, L. rhamnosus $G G$, and S. thermophilus lyophilized powders were activated in skim milk and subsequently kept at $4^{\circ} \mathrm{C}$. Sterilized Skim milk containing 5\% inoculum of activated strain was used for the preparation of mother culture. The incubation of mother cultures of L. delbrueckii ssp. bulgaricus and S. thermophilus were conducted at $42^{\circ} \mathrm{C}$ and the incubation of L. rhamnosus $G G$ mother culture at $37^{\circ} \mathrm{C}$. They were then placed at a temperature of $4^{\circ} \mathrm{C}$ until the texture of the curd became firmer. A filter cloth was used to purify the raw goat milk. After the addition of sugar, pasteurization of goat milk was carried out at $95^{\circ} \mathrm{C}$ for $5 \mathrm{~min}$ and then subsequently cooled to $45^{\circ} \mathrm{C}$. The goat milk was then inoculated with given strains in different ratios. Finally, the fermentation of goat milk was carried out at $4^{\circ} \mathrm{C}$. Results suggested that high quality goat milk yogurt was obtained in addition to Lactobacillus delbrueckii ssp. bulgaricus, Streptococcus thermophilus, and L. rhamnosus GG in the ratio 1:1:3 at fermentation temperature of $42^{\circ} \mathrm{C}(54)$.

Sumarmono et al. (55) prepared stirred-type goat milk yogurt by using different cultures. Firstly, the pasteurization of milk was carried out by using low temperature long time methods at a temperature of $63^{\circ} \mathrm{C}$ for $30 \mathrm{~min}$. Then the $5 \%(\mathrm{w} / \mathrm{w})$ previously activated yogurt culture (lyophilized) containing L. achidophylus, $L$. bulgaricus, and $S$. thermophiles are added into stirred-type yogurt sample. At a temperature of $40^{\circ} \mathrm{C}$ for $5 \mathrm{~h}$, the sample was incubated in a tightly sealed stainless-steel container. The yogurt was then moved into a sterile cheese cloth for partially removing its whey by tying up and hanging it in a cold room for $24 \mathrm{~h}$. The end product was concentrated yogurt with a creamy texture and

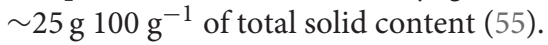

Feng et al. (56) prepared a novel goat milk dairy product through the utilization of jujube pulp. Initially, raw goat milk (containing 3\% fat and around 10\% non-fat solids) was filtered, pasteurized, and then cooled to $4^{\circ} \mathrm{C}$. Following that, concentrated jujube pulp was mixed with the goat milk at the concentrations (wt/wt) of $0,3,6$, and $9 \%$ naming it as $\mathrm{Y} 0, \mathrm{YJ} 3$, YJ6, and YJ9 sample. The mixture was stirred continuously by placing it in a water bath at a temperature of $90 \pm 2^{\circ} \mathrm{C}$ for $5 \mathrm{~min}$. The samples were inoculated with $3 \%$ reactivated YO-MIX187 Yogurt cultures including Lactobacillus delbrueckii ssp. bulgaricus and Streptococcus salivarius ssp. thermophilus after cooling to $42^{\circ} \mathrm{C}$. The inoculated samples were kept at $42 \pm 2^{\circ} \mathrm{C}$ for $6 \mathrm{~h}$ until coagulation occurred, and then the resultant goat milk yogurt products were refrigerated at $4^{\circ} \mathrm{C}$ for 28 days. Triplicates of all jujube goat milk yogurt products were developed. YJ3 sample, on the other hand, has the desired water holding capacity, adhesiveness, and hardness. Additionally, the inclusion of jujube pulp significantly diminished the goaty flavor, enhancing the sensory acceptability, and increasing the antioxidant activity of goat milk yogurt (56).

\section{Processing of Evaporated Goat Milk Powder}

The basic concept involved in the system of evaporation is the condensation of steam or vapor toward one end of a metal surface in heat exchangers, forcing the liquid on another end to develop into vapor. Evaporated goat milk is produced in the same manner as the products from cow milk. Evaporation is often performed at lower pressure for two reasons: first, to allow boiling at a relatively reduced temperature and therefore avoid heat damage, and second, to promote evaporation in more than one stage. The falling film type of evaporator is generally utilized in nearly all evaporation units. In this design, The flow of liquid is on the inner surface of several plates or pipes as a thin film through the action of gravity, while the presence of the heating medium is outside (57-60). For dried milk products, two distinct processing processes are utilized in the production of powdered milk: spray drying and roller drying. The process of spray drying converts fluid milk into a dried particle through the action of milk spraying into a hot drying medium. Conventional spray drying generally consists of four process stages: (i) milk atomization into a spray, (ii) spray drying through the contact of air (flow and mixing), (iii) spray drying through evaporation of water, and (iv) isolation of the dried product from the air (33). In the process of roller drying, processed milk or milk concentrate is spread as a thin film on the surface of the metal drum, which is rotating and steam-heated. The film of milk is dried and is continually scraped off by utilizing a stationary knife placed against the application point of concentrate during the rotating process (61).

Nascimento et al. (59) obtained goat's milk powder through the utilization of a semi-industrial spray dryer (LABMAQ model SD10) and open cycle mode in which atmospheric air acts as a drying gas. The goat milk used had a $13 \%(\mathrm{~kg} / \mathrm{kg})$ initial concentration of solids. The goat milk feed rate of $2 \mathrm{~kg} / \mathrm{h}$, the inlet temperature of $130 \pm 2^{\circ} \mathrm{C}$ and outlet temperature of 
$90 \pm 1^{\circ} \mathrm{C}$ of spray dryer, and $288 \pm 5 \mathrm{~kg} / \mathrm{h}$ of drying airflow rate was used during the operation. A two-fluid nozzle with a $2 \mathrm{~mm}$ diameter of orifice and gas flow rate of $2 \pm$ $0.1 \mathrm{~kg} / \mathrm{hr}$ was utilized for atomization to produce droplets of goat milk. Since the monolayer value of $2.404 \%$ showed that the powder is better stable at a moisture content of $2.4 \%$, it concluded that $2.4 \%$ should be a targeted moisture content for the powder after the spray drying process. According to the range of water activities when this moisture content is between 0.2 and 0.3 , this conclusion is validated and is regarded as a safe storage zone (59). It is observed that $S$. aureus has the potential of spreading throughout the goat milk powder in different producing locations. Goat milk powder production stages are also prone to cross-contamination with $S$. aureus. The presence of $S$. aureus strains in the goat milk powder may pose a public health risk. Hence, proper care and safety protocols should be followed to avoid the possible contamination of $S$. aureus in goat milk powder (62).

\section{PRESERVATION OF GOAT MILK BY NOVEL TECHNIQUES}

The goat milk business is unable to compete with its dairy cow counterpart in terms of the overall volume of output due to the lesser scale of milk production than for cow milk and the seasonal milk availability. This species-specific intrinsic disadvantage of the dairy goat business demands the investigation of various alternative and sophisticated technical solutions for year-round supplying of goat milk products, as well as improving productivity, quality, distribution, and storage (63). Cleaning udders before milking is required, with specific attention paid to end teats, employing predipping solutions, followed by utilization of paper towel to dry teats, resulting in avoidance of residues in milk. The person responsible for milking must be in good health, fully wash his or her hands, be smoke-free, and wear clean clothes. The initial squirt of milk must be collected in a black bottom jar when milking, as well as monitoring anomalies in milk and rejecting milk with a relatively greater bacterial count, to maintain higher milk quality. It is preferable to do CMTs (California Mastitis Tests). To obtain all of the milk, the milking process should be quick and calm. After milking, it is critical to undergo a dipping process in which the teats are immersed in a solution of glycerinated iodine and the goats are not allowed to lie down for a period of 30-60 $\mathrm{min}$. When they return to the barn after milking, a smart strategy is to offer them the required diet (64).

Finally, there is the process of milk storage. When the milk initially exits the doe, it is usually at body temperature and therefore should be chilled to $4^{\circ} \mathrm{C}$ as quickly as possible for the optimum flavor and quality. Some manufacturers chill their milk in a freezer, ice, or cold water bath $(63,64)$. The cooling of goat milk must be exhibited immediately after milking to the 36$42^{\circ} \mathrm{F}$ holding a range of temperature, and it is mandatory in maintaining that temperature until the process of processing as well as throughout transit to a dairy plant (44).

\section{Preservation by Heat Treatment and low Temperature}

Microbial growth has a detrimental effect on the physicochemical characteristics and shelf life of raw as well as processed milk $(65,66)$. The growth of microbes reduces the shelf life of pasteurized milk by generating unwanted characteristics and causing a change in sensory properties. As a result, customers have faced severe issues with microbiological safety and product quality preservation. Heat processing is an old, efficient, and easy method for treating dairy and its products. It is used to decrease the bacteria count in raw milk as well as to improve the sensory qualities of milk components and nutritional benefits $(35,67)$. The pasteurization process can help in the reduction of the bacterial count in raw milk, which is crucial for enhancing milk shelf life. The procedure, on the other hand, does not affect milk composition or fatty acid profile (68). Caprine milk's high ionic calcium concentration and poor micellular solvation may lead to thermal instability. Goat milk is considered to be extremely sensitive to heat treatment; it is typically unable to survive ultra-high temperature (UHT) treatment. Several techniques, including $\mathrm{pH}$ modification, the inclusion of a calcium sequestrant, and preheating of milk, have been believed to enhance heat stability and maintain UHT procedures for goat milk $(37,69)$. To avoid an enzymatic breakdown that may occur during the storage of goat milk, pasteurization can be performed before UHT sterilization. The indirect procedure is the most commonly used UHT treatment, although the direct process, which uses steam injection and infusion, can also be used. Heat stability of milk is critical in the production and processing of dairy products, particularly in the creation of goat milk products. The majority of heat stability tests on goat milk have revealed that it is quite sensitive to heat treatment $(1,33)$.

The research was carried out on the pasteurization of goat milk at different time and temperature combinations (72, 75, and $81^{\circ} \mathrm{C}$ for 15 and $25 \mathrm{~s}$ ). The study found that heat treatments between $72^{\circ} \mathrm{C}$ for $25 \mathrm{~s}$ and $75^{\circ} \mathrm{C}$ for $25 \mathrm{~s}$ resulted in the greatest stability of pasteurized goat milk for up to the storage of 3 weeks at a temperature of $4^{\circ} \mathrm{C}$. The two treatments had no significant impact on the nutritional, physicochemical, microbiological, antioxidant, and quality parameters of pasteurized goat milk. Although $81^{\circ} \mathrm{C}$ had a superior preservation effect, other goat milk-keeping characteristics were considerably impacted. As a consequence of the findings, suitable heat treatments can improve goat milk quality while decreasing psychrotrophic and mesophilic counts and extending goat milk's microbiological stability (70). It was demonstrated that the pasteurization technique of hightemperature short-time (HTST) was considered superior for preserving different vitamins and extending the shelf-life of goat milk. In terms of riboflavin, thiamine, and vitamin C preservation in goat milk, the flash, HTST, and UHT procedures outperformed the autoclave treatment and LTLT (low-temperature long-time) techniques. Pasteurization is carried out per standards of US FDA or EU requirements. The manual and batch type of milk pasteurization is generally done at $145^{\circ} \mathrm{F}\left(62.8^{\circ} \mathrm{C}\right)$ for $30 \mathrm{~min}$ $(33,71,72)$. 
The storage of raw goat milk at a temperature of $4^{\circ} \mathrm{C}$ for the period of 1,3 , and 5 days results in unaffected goat milk composition of lactose, ash, moisture, total solids, proteins, and fats (73). Similar results regarding the unaffected composition of goat milk during cold storage were observed in many other studies around the world. A study on the evaluation of refrigerated raw goat milk storage influencing the quality of whole milk powder suggested that to protect the quality of goat milk powder during its 180-day shelf life, raw goat milk should be stored at $4^{\circ} \mathrm{C}$ for no more than 3 days (73). The time-temperature indicator, also known as the time-temperature integrator (TTI), is a straightforward smart packaging indication that uses natural dyes as a source of indicators. The dye may vary in reaction to product changes during storage. The utilization of synthetic dyes such as bromothymol blue and methyl red or natural types of dyes involving yellow betaxanthin pigments and red-violet betacyanin, obtained from red dragon fruit can be exhibited $(74,75)$, conducted a study to assess the fresh quality of goat milk when stored for 31 days at freezing temperatures $\left(-20 \pm 2^{\circ} \mathrm{C}\right)$ and $24 \mathrm{~h}$ at room temperature $\left(25 \pm 2^{\circ} \mathrm{C}\right)$, by utilization of bioindicator films placed externally on milk bottles. The results revealed that color alterations in the bioindicator film were more visible at room temperature, compared to that of freezing temperature. Based on the color variations of the bioindicator at room temperature, the consumption of the sample was considered safe until the fifth hour with a $\mathrm{pH}$ of 6.51 . Fresh goat milk with a $\mathrm{pH}$ of 6.51 was safe to consume even at freezing conditions until the 31 st day.

\section{Hydrostatic High-Pressure Treatment}

The treatment by HHP is a novel method of food preservation. This procedure can improve texture as well as the presence of dormant harmful bacteria (76). It has been utilized in the enhancement of goat milk and increased the retention of nutritional content, color, and flavor $(77,78)$. HHP may also affect rates of an enzymatic reaction, and its usage may result in denaturation of whey proteins, disrupting casein micelles, and changing the textural properties (79). High pressure processing entails semicontinuous or batch treatment of product around $800 \mathrm{MPa}(8,000 \mathrm{bar})$ pressure. The flexible packaging is generally utilized for the packaging of the product, consisting of little headspace and usually placed in a vessel filled with water or containing different pressure-transmitting fluid. After that, the vessel is sealed, and the fluid (responsible for transmitting the pressure) is injected into the system until the necessary pressure is attained. The system is retained at this pressure for the required holding period, and then the pressure is released, allowing the vessel to be opened, the treated product removed, and the new product fed into the system for the next cycle (80). The degree of microbial inactivation is determined by the pressure used, the temperature, the environment, the duration of treatment, and the quantity and kind of microorganisms. In terms of technology, HHP provides a possible pasteurization alternative to heat treatment. The application of pressures between 300 and $600 \mathrm{MPa}$ inactivate molds, yeasts, and the majority of vegetative bacteria. Only bacterial spores can withstand pressures beyond 1,000 MPa pressure, although spores can be inactivated by heat treatment or moderate pressure if germinated at 50-300 $\mathrm{MPa}(81)$.

\section{Ultrasound Treatment}

In comparison to other processing methods, the utilization of ultrasound techniques in food processing is pretty new (82). It is considered to be a non-toxic and environmentally friendly method used in the North American dairy industry to homogenize and emulsify milk. It enhances the texture and viscosity properties of fermented products through the application of high power (above $100 \mathrm{~W}$ ) and a low frequency of around 20 and $45 \mathrm{kHz}$. It may also aid in enhancing the products' soluble phosphorus and calcium content, which is directly connected to the textural and rheological features of fermented dairy products (76). When employed at high frequencies (18$100 \mathrm{kHz}$ ), ultrasound can stimulate or kill live cells, alter enzyme activities, increase extraction or impregnation of components, and enhance emulsion, freezing, and crystallization processes (82). The technique used in ultrasound is based on acoustic waves flowing through a specified material at a relative speed determined by the type of the wave and the substance through which it travels. Bacteria can be inactivated by ultrasound therapy, however, the amount of inactivation is dependent on the kind of bacterial cell and various treatment circumstances (80).

The major phenomenon associated with the ultrasonic process is "cavitation," in which through the action of rapid collapse and rectified diffusion, liquid bubbles are developed. The implosion and oscillation of bubble cavitation can lead to disruption of cells, shock waves, shear forces, change in pressure and temperature, production of free radicals as well as turbulence (83). Ragab et al. treated goat milk with ultrasound for 15-30 min at a frequency and power output of $20 \mathrm{kHz}$ and $12.1 \pm 0.89 \mathrm{~W}$, respectively. The results showed that the shear forces produced from ultrasound decreased particle size, changed the protein secondary structure, and enhanced the content of its $\beta$-sheet, resulting in improving its surface hydrophobicity. The prolonged period of ultrasonic treatment resulted in the enhancement of microstructure, elasticity, and rheological property of the rennet-induced gel. As a result, ultrasonic technology might be used in the dairy industry to improve the quality of rennet coagulation during the manufacturing of goat milk cheese (83). In addition, after being exposed to ultrasound for $6 \mathrm{~min}$, the apparent viscosity and consistency index of several yogurt samples obtained from goat milk was considerably improved (84).

\section{Ultrafiltration Treatment}

The advanced separation technologies serve as the foundation for adding value to milk processing (85). The dairy industry utilizes the technique of membrane separation such as reverse osmosis and ultrafiltration in concentrating and removing components from milk. These procedures are also utilized to enhance the dry matter of milk, which benefits dairy products' textural and rheological characteristics $(76,86)$. Membranes are already used in a variety of dairy technology sectors such as processing of whey, fractionation of milk fat, processing of milk protein, and demineralization or desalination (87). 


\section{Microfiltration Treatment}

Microfiltration is a type of membrane separation technique identical to ultrafiltration except that the membrane pore sizes are larger, allowing particles with diameters ranging from 0.2 to $2 \mu \mathrm{m}$ to pass through it. It is a non-thermal type of treatment method for reducing the presence of bacteria and improving the microbiological safety of dairy products while retaining flavor and taste (87). Due to the capability of removal of cells, microfiltration can also be utilized by the dairy sector to lower somatic cell count. However, because of size changes in fat particles, this treatment may alter the technical milk appropriateness for the processing of other products (77). Microfiltration seems to be a promising approach for producing whey fruit juice beverages with similar rheological characteristics used in the dairy sector to make whey fruit juice beverages with comparable rheological properties to samples that are conventionally processed at lower temperatures, that could be beneficial for nutritional compounds (88). Vieira et al. evaluated the functional, microbiological, and physicochemical qualities of a novel microfiltered goat whey orange juice beverage (GWOB). When compared to the standard LTLT treatment $\left(63^{\circ} \mathrm{C} / 30 \mathrm{~min}\right)$, the different temperatures of feed at $20,30,40$, and $50^{\circ} \mathrm{C}$ impacted the microfiltration $(0.2 \mu \mathrm{m})$ of the GWOBs. The temperature of microfiltration affected the rheological properties and adopting $20^{\circ}$ and $30^{\circ} \mathrm{C}$ temperatures kept a similar consistency to that of the LTLT sample while maintaining the texture components. Thus, it is suggested that GWOB should be processed through microfiltration at optimum temperatures of $30^{\circ}-40^{\circ} \mathrm{C}$ to preserve homogeneity, volatile components, functional properties and obtain better quality of microbial population (88).

\section{Pulse Electric Field Treatment}

The principle of food products treated with PEF is to focus on the development of high-intensity electric fields to products in the form of relatively shorter pulses. Field intensities are typically in the $10-80 \mathrm{kV} / \mathrm{cm}$ range, with pulse durations ranging from 0.1 to $5 \mu \mathrm{s}$. The design of the treatment chamber should allow for the establishment of a spatially uniform field distribution, the minimization of dwell time dispersion, and the regulation of temperature. PEF may be used in a wide range of waveforms. Exponentially decaying pulses, which consist of a unidirectional voltage that gradually rises to a peak and then exponentially decays to zero, are commonly employed. However, square and bipolar types of waveform pulses are more effective than exponentially declining waveform pulses for the inactivation of microbes (80).

PEF is a new alternative pasteurizing process that, when used appropriately, has the potential to increase the shelf life while reducing the negative effects on the organoleptic characteristics of goat milk. The findings indicate that monopolar PEF pasteurization can be suggested to improve the goat milk quality at the industrial level. Because of the growing need for greater nutritional content and fresh-like characteristics in processed foods, non-thermal treatments such as PEF have gained traction as a replacement for thermal pasteurization (57, 89-91). PEF is used at room temperature $\left(20-25^{\circ} \mathrm{C}\right)$ and has a short treatment period, generally $<1 \mathrm{~s}$. Because of its cheap processing cost, little energy loss, and environmental friendliness, the outcomes of PEF processing are encouraging in the food and beverage production industries $(57,89)$. The research on the application of PEF on goat milk suggested that treatment of PEF at $40 \mathrm{kV} / \mathrm{cm}$ for $10 \mathrm{~s}$ resulted in substantial alterations in the titratable acidity and $\mathrm{pH}$ value of the treated samples due to a reduction in calcium ion $\left(\mathrm{Ca}^{+}\right)$, which leads to the phosphate protonation. At $20 \mathrm{kV} / \mathrm{cm}$ for period of $5 \mathrm{~s}$, other physicochemical properties such as color, TSS, and viscosity were shown to have non-significant impacts. Furthermore, it was discovered that the PEF processing and parameters utilized in this study were free from contamination of heavy metal. To summarize, this study found that PEF has a high potential for utilization in treatment of milk pasteurization due to little changes in the organoleptic and physicochemical features of treated goat milk during milk processing (92).

\section{HEALTH BENEFITS}

Milk is a source of nutrition for newborn mammals, as well as children and adults, and it is used for growth and sustenance. It is frequently regarded as a functional food because it exhibits potential bioactive compounds, such as whey proteins and casein, which are discovered to be highly significant for biochemical and physiological functions with a profound influence on human health and metabolism (10). In the current scenario, there is an increase in the importance of goat milk due to its unique composition and thus it is utilized as a superior raw material for the production of food for infants and the elderly, as well as for some segments of the population with special dietary requirements $(93,94)$. Because of its nutritional richness, digestibility, dietary and therapeutic potential, goat milk is becoming an indispensable part of the human diet (3). In addition to the presence of high-quality protein, goat milk comprises unsaturated fatty acids, vitamins, hormones, cytokines, enzymes, growth factors, and bioactive peptides, all of which assist to nourish and protect infants (95-97). Besides nutritional benefits of milk components, additional components such as antibodies, glycoproteins, and oligosaccharides can protect infants by preventing pathogen infections and supporting the growth of the intestinal epithelium (98). Various health benefits of goat milk are shown in Table 3. A general overview of the processing of goat milk, bioactive compounds, and its health benefits are shown in Figure 1.

Goat milk has been known for its therapeutic and hypoallergenic characteristics in human health and nutrition, implying that caprine milk may include metabolically active and bioactive components that are specific to this species' milk. Considering the bioactive milk components, goat milk's hypoallergenic properties are crucial to human health and medicine. This concept has gained the interest of goat milk consumers and producers worldwide, particularly in developed nations in recent years (104). In a recent study, goat milk treatment cured a large population of children suffering from cow milk allergies; and in another allergy case study, 49 of 55 treated children benefited from goat milk treatment (102). Grant 
TABLE 3 | Health benefits of goat milk.

\begin{tabular}{|c|c|c|c|c|}
\hline Sr. No. & Milk component & Health benefit & The possible outcome from the study/research & References \\
\hline \multirow[t]{8}{*}{1} & Casein & Anti-viral property & $\begin{array}{l}\text { According to preliminary data, the process is non-specific and is mediated by a } \\
\text { casein fraction component. This fraction is most likely comprised of one or more } \\
\text { distinct components that interact with the capsid receptors or membrane of different } \\
\text { viruses, therefore preventing cell entry and replication of pseudo virus SARS-CoV-2, } \\
\text { Coxsackievirus A9, and HSV-1 viruses }\end{array}$ & (99) \\
\hline & & Anti-diabetic & $\begin{array}{l}\text { Casein hydrolysates present in goat milk have the potential to improvise insulin } \\
\text { resistance and treatment of type- } 2 \text { diabetes }\end{array}$ & $(100)$ \\
\hline & & $\begin{array}{l}\text { Anti-hypertensive and } \\
\text { immuno-stimulating }\end{array}$ & $\begin{array}{l}\text { Caprine milk } \beta \text {-Casein can generate immune-stimulating and anti-hypertensive } \\
\text { peptides }\end{array}$ & $(101)$ \\
\hline & & $\begin{array}{l}\text { Angiotensin-converting } \\
\text { enzyme inhibitors (ACE } \\
\text { inhibitors) }\end{array}$ & $\begin{array}{l}\text { Identification of } \beta \text {-Casein } f 58-65 \text { and } \alpha \text { s-Casein } 1182-187 \text { in caprine milk have the } \\
\text { potential in producing ACE-inhibitory peptides }\end{array}$ & $(1)$ \\
\hline & & Anticariogenic effects & $\begin{array}{l}\text { Calcium-binding Casein phosphopeptides (CPP) present possess anticariogenic } \\
\text { properties via preventing caries lesions by recalcification of the tooth enamel, as well } \\
\text { as competing for calcium from dental plaque-forming bacteria }\end{array}$ & (1) \\
\hline & & Antioxidant property & $\begin{array}{l}\text { Peptides produced from } \alpha \text { s-casein exhibit free radical-scavenging action and prevent } \\
\text { both non-enzymatic and enzymatic lipid peroxidation }\end{array}$ & $(1)$ \\
\hline & & $\begin{array}{l}\text { Antagonistic or } \\
\text { agonistic activity }\end{array}$ & $\begin{array}{l}\text { The peptides present in } \beta \text { - and } \alpha \text {-casein are known to function as opioid peptides, } \\
\text { exhibiting antagonistic, or agonistic effects }\end{array}$ & $(102)$ \\
\hline & & Cytomodulatory effect & $\begin{array}{l}\text { Caseinophosphopeptides (CPPs) have been shown to have cytomodulatory } \\
\text { properties by suppressing the development of cancer cells or promote the function of } \\
\text { immunocompetent cells }\end{array}$ & $(103)$ \\
\hline 2 & $\begin{array}{l}\text { Casein and whey } \\
\text { protein }\end{array}$ & $\begin{array}{l}\text { Immunomodulatory } \\
\text { effect }\end{array}$ & $\begin{array}{l}\text { Immunomodulatory effects of peptides and protein hydrolysates obtained from major } \\
\text { whey proteins and milk caseins include the proliferation of lymphocytes, production of } \\
\text { antibodies, and cytokine modulation }\end{array}$ & $(10)$ \\
\hline \multirow[t]{3}{*}{3} & Whey protein & Antioxidant property & $\begin{array}{l}\text { Whey protein processed at low temperature includes a relatively increased number of } \\
\text { certain dipeptides (glutamylcysteine), which can increase glutathione production, an } \\
\text { essential antioxidant essential in cellular protection and repair activities }\end{array}$ & $(104)$ \\
\hline & & Anti-appetizing effect & $\begin{array}{l}\text { The total content of whey protein present in the diet has been related to decreased } \\
\text { LDL cholesterol and increased production of cholecystokinin (appetite-suppressing } \\
\text { hormone) }\end{array}$ & $(10)$ \\
\hline & & ACE inhibitors & $\begin{array}{l}\text { The hydrolysate of caprine }(\beta-L g) \text { produced with termolisin yielded four novel } \\
\text { ACE-inhibitory peptides }\end{array}$ & $(1)$ \\
\hline 4 & Milk protein & Anti-thrombotic activity & $\begin{array}{l}\text { Caprine } к-C M P \text { and its hydrolysates with trypsin inhibited the aggregation of human } \\
\text { platelet }\end{array}$ & $(105)$ \\
\hline 5 & Lactoferrin & Anti-microbial activity & $\begin{array}{l}\text { A peptide derived from lactoferrin (Lactoferricins) has anti-microbial action against a } \\
\text { variety of Gram-negative and positive- bacteria, fungi, and yeast }\end{array}$ & $(106,107)$ \\
\hline 6 & Fatty acids & Hypocholesterolaemia & $\begin{array}{l}\text { Fatty acids present are known to exhibit a hypocholesterolemic effect on blood and } \\
\text { tissue through inhibition of dissolution and deposition of cholesterol in gallstones }\end{array}$ & (1) \\
\hline 7 & Phospholipid & - & $\begin{array}{l}\text { Phospholipids aid in fat absorption by forming a barrier around the fat globules, which } \\
\text { keeps them finely distributed. Through their lipotropic action, phospholipids aid in the } \\
\text { transfer of fat from the liver }\end{array}$ & $(1,104)$ \\
\hline 8 & $\begin{array}{l}\text { Medium-chain } \\
\text { triglyceride (fat) }\end{array}$ & Energy providing effect & $\begin{array}{l}\text { Because MCT is a readily accessible energy substrate, goat milk has a substantial } \\
\text { influence on supplying energy, particularly in developing youngsters }\end{array}$ & $(108)$ \\
\hline 9 & Cholesterol & - & $\begin{array}{l}\text { It is considered a metabolic precursor of bile acid and vitamin D. It is essential for } \\
\text { metabolic processes involved in DNA synthesis, transportation of lipid, and cell } \\
\text { division }\end{array}$ & $(102)$ \\
\hline \multirow[t]{3}{*}{10} & Oligosaccharide & Cell protection activity & $\begin{array}{l}\text { They help in the protection of intestinal mucosa cells against infections by } \\
\text { encouraging the development of Lactobacillus bifidus in the digestive tract, } \\
\text { particularly in infants }\end{array}$ & $(109)$ \\
\hline & & Anti-inflammation & $\begin{array}{l}\text { They help in decreasing intestinal inflammation and aid in the repair of damaged } \\
\text { colonic mucosa in rat studies }\end{array}$ & $(110)$ \\
\hline & & $\begin{array}{l}\text { Prebiotic } \\
\text { anti-pathogenic effect }\end{array}$ & $\begin{array}{l}\text { The oligosaccharides present in goat milk help in exhibiting anti-pathogenic and } \\
\text { prebiotic effects, associated with enhancement of central nervous system and can be } \\
\text { used in supplementation of milk formulation as an alternative to other milk }\end{array}$ & $(111,112)$ \\
\hline 11 & Minerals & $\begin{array}{l}\text { Enhanced mineral } \\
\text { uptake }\end{array}$ & $\begin{array}{l}\text { In rats, a goat milk-based diet boosted iron deposition in target organs while } \\
\text { decreasing anemia }\end{array}$ & $(113)$ \\
\hline
\end{tabular}


TABLE 3 | Continued

\begin{tabular}{|c|c|c|c|c|}
\hline Sr. No. & Milk component & Health benefit & The possible outcome from the study/research & References \\
\hline & & $\begin{array}{l}\text { Increase mineral } \\
\text { bioavailability }\end{array}$ & $\begin{array}{l}\text { The consumption of goat milk in rats resulted in increased bioavailability of selenium, } \\
\text { zinc, and copper than cow milk-fed rats }\end{array}$ & $(114,115)$ \\
\hline 12 & - & $\begin{array}{l}\text { Increase in overall } \\
\text { nutrition }\end{array}$ & $\begin{array}{l}\text { Rats fed GM thrived substantially better, had greater liver weights, enhancement in } \\
\text { hemoglobin iron content, and its absorption }\end{array}$ & $(1)$ \\
\hline 13 & - & Allergy & Goat milk delivery and feeding alleviated gastrointestinal allergies in some infants & $(104)$ \\
\hline 14 & - & $\begin{array}{l}\text { Promotion of growth } \\
\text { factors }\end{array}$ & $\begin{array}{l}\text { GM contains a significantly greater concentration of growth factors, and a human } \\
\text { epidermal growth factor (hEGF) polyclonal antibody was used to detect the existence } \\
\text { of EGF in caprine milk }\end{array}$ & $(18)$ \\
\hline 15 & - & Antioxidant property & $\begin{array}{l}\text { GM fermented with Lactobacillus fermentum (M4) had remarkable antioxidant } \\
\text { activities }\end{array}$ & $(116)$ \\
\hline
\end{tabular}

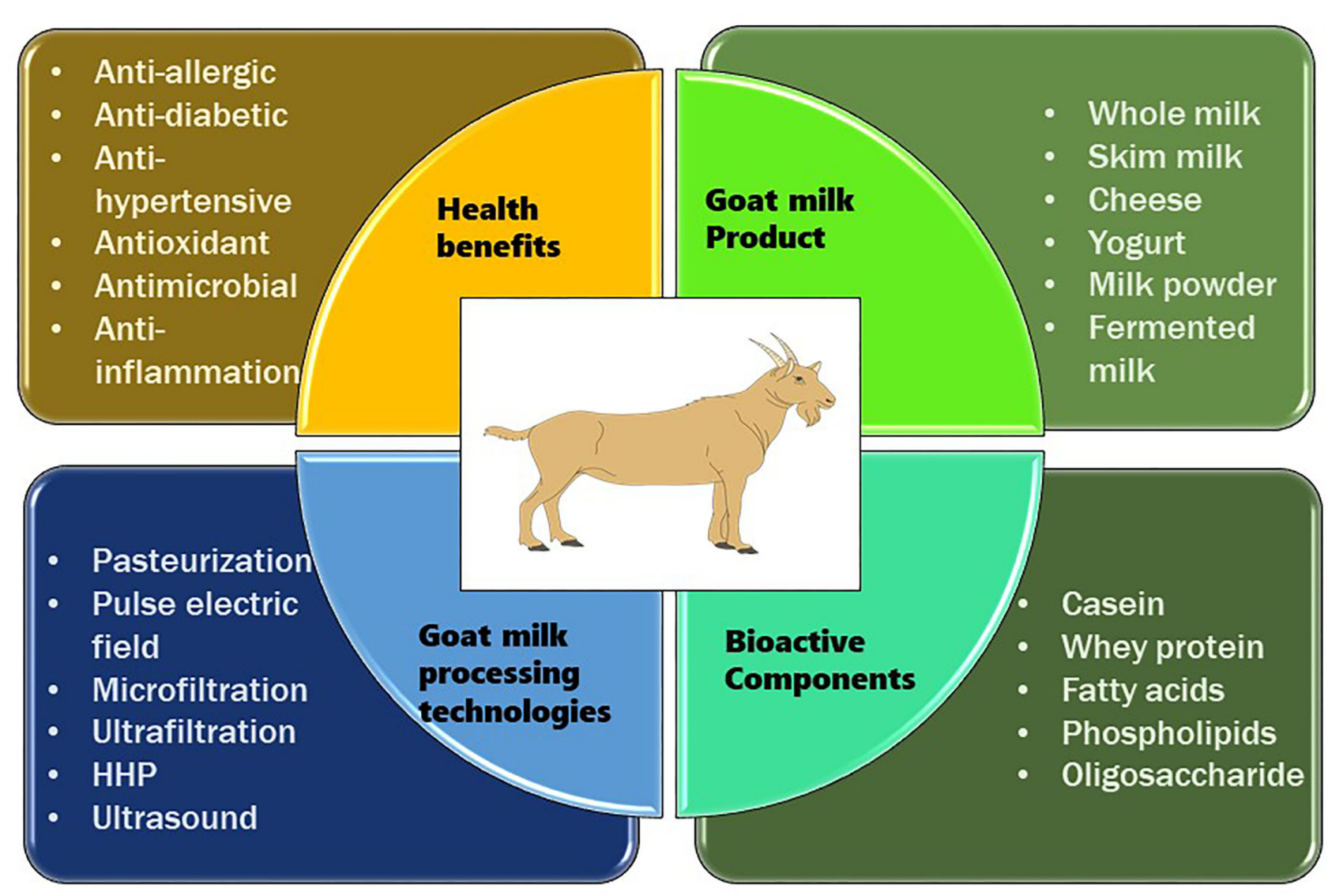

FIGURE 1 | Processing, bioactive compounds, \& health benefits of goat milk.

et al. observed a non-significant increased weight gain in infants $(N=36)$, which were fed with infant formula based on goat milk than in those fed with infant formula based on cow milk, even though the study of both formulae had identical macronutrient and nutritional (energy) composition (117).

Goat milk has a better buffering capacity than cow milk due to its relatively higher content of protein, phosphate content, and non-protein N. Some of the physicochemical characteristics of goat milk, such as shorter fat globules, softer curd creation, and a greater percentage of medium and short-chain fatty acids, are beneficial for higher digestion and better metabolism of lipid when compared to cow milk (10). In their study (118) found that giving goat milk rather than cow milk in the diet resulted in higher biliary production of cholesterol and a decrease in the content of plasma cholesterol. The bile acid and phospholipid outputs, as well as the lithogenic index, remained within normal limits. Furthermore, consumption of goat milk reduces plasma triglyceride concentrations and thus has a positive effect on the metabolism of lipid identical to that of consumption of diet including virgin olive oil (64). 
Several investigations have reported goat milk as a functional food attributed to its nutritional profile and health benefits, beneficial alteration of physiological processes, and decrease of risk from chronic ailments (3). Furthermore, it has been demonstrated that daily consumption of goat milk reduces acute inflammation, lowers exaggerated basal secretion of interleukin IL-6 (IL)-8 and acute response, and generates a modest downregulation of IL- $1 \beta$ and production of tumor necrosis factor$\alpha$ in immune-compromised elderly patients $(48,119)$. The ratio of omega- 6 to omega-3 fatty acids in goat milk fat is $5: 1$, which is comparable to the ratio suggested for human cardiovascular disease prevention. Because CLA consumption can reduce body fat by blocking lipogenesis and increasing lypolysis, pasture-raised goats are the optimal strategy to enhance milk CLA content (120). In hypercholesterolaemic rats, goat milk casein and fat fraction lowered plasma cholesterol, elevated High-density lipoprotein cholesterol, enhanced fecal cholesterol excretion, and demonstrated antioxidative characteristics. These goat milk properties suggest that it may protect against disorders associated with higher cholesterol levels, such as atherosclerosis, as well as decrease the accumulation of free radicals and ROS, thereby protecting cell membranes from damage by oxidation (121).

Dairy goats are being used in livestock interventions in Malawi and Sub-Saharan Africa, where there are few or no infant formulas available for HIV-positive mothers in impoverished rural families. Mothers with HIV/AIDS are encouraged to exclusively breastfeed their newborns for the first 6 months since there is a decreased chance of viral transmission to the child during this time. After the period of 6 months, mothers are encouraged to discontinue breastfeeding and utilize milk replacements that are inexpensive, acceptable, readily available, sustainable, and safe. For this purpose, goat milk is considered to be an excellent choice (122). Furthermore, the inclusion of probiotics-live bacteria that, when consumed in sufficient quantities, provide advantages to the host-can increase the functional value of goat milk (21). Consumer demand has driven the dairy sector to create products with useful components, such as the inclusion of prebiotic compounds or probiotic microorganisms (123). The goat milk based functional products containing probiotics and prebiotics has received the dairy industry's attention for commercial and scientific reasons attributed to their immense health benefits (3). goat milk was reported to have a distinct antiviral impact, which is reduced but not eliminated by pasteurization. Goat milk outperformed bovine milk in terms of antiviral effectiveness. Similarly, goat milk aids in suppressing other viruses such as pseudovirus SARS-CoV-2 and Coxsackievirus A9 in addition to HSV-1 $(99,124)$. Thus, goat milk is more than just a "grandmother medicine"; this action is caused by casein in goat milk, and pasteurization decreases this effect (99).

Goat milk products are regarded to be the most marketable dairy products. As a result, various features of goat milk are generating significant research attention at the moment (48). The white brined goat milk cheese made with Lactobacillus casei and Lactobacillus bulgaricus possess the highest ACE-inhibitory and antioxidant activity (125). The antioxidant characteristics of goat milk kefir fermented with kefir grains were mostly determined by the fermentation and storage times, and the product demonstrated excellent stability in ABTS, FRAPS, and DPPH assays (126). Crude protein extract derived from goat milk whey has the potential to act as a bacteriostatic, cytotoxic compound for the destruction of tumor cells, and a potent antioxidant (127). The preventive effects of goat milk and goat yogurt on intestinal damage caused by acetic acid are similar to those of sulfasalazine, suggesting that goat milk and goat yogurt could be used as functional foods in inflammatory bowel disease (128).

The anti-inflammatory activities of lipids in goat and sheep products have been studied in traditional Greek Ladotyri and Kefalotyri sheep cheeses (129), and the lipid fractions of both kinds of cheese exhibited inhibitory activity toward PAF-induced platelet aggregation. Further analysis of the lipid fractions in both cheese, by thin layer chromatography, has shown that the most biologically active lipid fractions contained sphingomyelin, phosphatidylcholine, and phosphatidylethanolamine lipid derivatives. However, these lipid fractions do not always present as a typical phospholipid structure; they share a similar structure to phosphatidylcholine derivatives as reported by Nasopoulou et al. (130). Poutzalis et al. compared the PAFinhibiting properties of goat products (milk, yogurt, and cheese), and all goat samples possessed PAF inhibitors (131). The presence of a greater concentration of medium- and shortchain triglycerides in goat milk have also been used to treat individuals with malabsorption who have chyluria, steatorrhea, intestinal resection, hyperlipoproteinemia, childhood epilepsy, coronary bypass, cystic fibrosis, premature infant feeding, and gallstones $(3,10,48)$. goat milk is said to have a higher buffering capacity, which might be useful in stomach ulcers treatment. The utilization of whole goat milk as the sole protein source in infant formulas maximizes the level of fat, milk fat globule membrane, sn-2 palmitic acid, and medium and short chain fatty acids. These characteristics enhance the microstructure and composition of whole goat milk-based infant formula, emulating the complex fat globules seen in human milk fat, and have been demonstrated to aid digestion, as well as cognitive and immunological development (132). Goat milk, particularly in developing nations, is a viable dairy alternative for meeting the nutritional needs of children, infants, and adults (1).

\section{WHAT DOES THE CURRENT REVIEW ADD TO THE EXISTING KNOWLEDGE?}

The previously published reviews, generally have focused on providing information on the nutritional content, processing technologies and health benefits of goat milk and its product $(3,10,16,18,33,48,94,105)$. This review provides the detailed comparison of the goat's feeding system in terms of pasture and indoor-based feeding, which conclusively suggested that pasture-based feeding enhances the fatty acid content of goat milk, resulting thus, in higher economic value and consumer benefit (24). The present review also highlights the recent insights about some alternative goat milk processing methods. The novel 
information about the production of different goat milk products incorporated with fruit juice, such as the preparation of goat milk yogurt with the inclusion of jujube pulp (56) and development of goat whey orange juice beverage using the microfiltration process (88), which not only masks the goaty flavor but also improves the overall nutritional and sensory profile of goat milk. More detailed research surely could set the basis for encouraging the development of functional beverages. Similarly, the utilization of bio-indicators described in the present study, developed for evaluating the quality and microbiology of goat milk at different times and temperature combinations could be considered as a novel method. This approach could be adopted for authenticating the quality of goat milk on commercial scale (75). Previous studies on goat milk suggeested the heatdependent pasteurization methods, but the latest research proved that pulsed electric field treatment could be used as an alternative to the conventional pasteurization method to obtain better results. Goat milk treated with $20 \mathrm{kV} / \mathrm{cm}$ for a period of $5 \mathrm{~s}$ showed similar results to conventional pasteurization, revealing its high potential for application as an alternative to conventional pasteurization method (92). Previous studies do not have definite information about the actual process and processing parameters for obtaining goat milk powder, but the study of Nascimento et al. (59) suggested some parameters in spray drying and other aspects of the process, to obtain an end product with very low moisture content $(2.4 \%)$ and water activity $(0.2-0.3)$, enhancing the shelf life and consumer acceptability of goat milk powder (59).

\section{CONCLUSION}

Goat milk could be considered as a significant option for consumption in nearly all age groups, compared to other milk obtained from different animal species. Apart from imparting various nutritional benefits, goat milk promotes a wide range of health benefits in humans. Various technologies have been used to improve the textural, sensory, and overall quality of goat milk and its products, resulting in increased customer acceptance. Bioactive peptides present in goat milk-

\section{REFERENCES}

1. Park YW. Goat milk - chemistry and nutrition. In: Park YW, Haenlein GFW, Wendorff WL, editors. Handbook of Milk of Non-Bovine Mammals. Oxford: John Wiley \& Sons, Ltd (2017). p. 42-83. doi: 10.1002/97811191103 16.ch2.2

2. Zobel G, Nawroth C. Current state of knowledge on the cognitive capacities of goats and its potential to inform species-specific enrichment. Small Rumin Res. (2020) 192:106208. doi: 10.1016/j.smallrumres.2020.10 6208

3. Verruck S, Dantas A, Prudencio ES. Functionality of the components from goat's milk, recent advances for functional dairy products development and its implications on human health. J Funct Foods. (2019) 52:24357. doi: 10.1016/j.jff.2018.11.017

4. Utaaker KS, Chaudhary S, Kifleyohannes T, Robertson LJ. Global goat! is the expanding goat population an important reservoir of cryptosporidium? Front Vet Sci. (2021) 8:183. doi: 10.3389/fvets.2021.648500

5. Watkins PJ, Jaborek JR, Teng F, Day L, Castada HZ, Baringer $\mathrm{S}$, et al. Branched chain fatty acids in the flavour of sheep based products have tremendous therapeutic potential by regulating the physiological and metabolic functions of the body. Goat milk and milk-based products exhibit excellent cholesterol properties by improving cholesterol mobilization and controlling its storage in the blood. Serum protein hydrolysates of goat milk have been reported to have ACE inhibitory activity, particularly $\beta$-lactoglobulin. The amino acid sequence of the ACE inhibitory peptides found in goat milk may also form the basis for the formulation of products with significant therapeutic potential. Angiotensin I-converting enzyme (ACE) inhibitors present in goat milk products have shown potential antihypertensive properties. Functional and nutraceutical properties of goat milk could be attributed to its strong bioactive potential and hence could be considered for future applications in the development of functional foods for the treatment of certain chronic diseases. Exploiting the use of novel technologies in the processing of goat milk and its product could pave way for new horizons in the development of functional foods based on goat milk attributed to its significant bioactive potential.

Looking at the processing potential of goat milk, it can be utilized for the formulation of numerous common dairy ingredients such as ice cream, butter, etc. as well as for the development of novel dairy products. It can also be used to develop different infant-based foods, and will surely be a gamechanger in infant foods if more and more detailed research is carried out. Goat milk is rich in bioactive compounds and functional ingredients, so its potential could be explored for the development of dairy based functional foods and nutraceuticals.

\section{AUTHOR CONTRIBUTIONS}

GN, MA, SA, and AHD contributed to the conception and design of the study. AHD proposed the title of the manuscript. YJ, SG, $\mathrm{HH}$, and AND wrote the first draft of the manuscript. GN, DD, and $\mathrm{OB}$ wrote sections of the manuscript. MR, AHD, and GN have revised the manuscript critically. All authors collated papers, read, and approved the final version of the manuscript. and goat milk and meat: a review. Small Rumin Res. (2021) 200:106398. doi: 10.1016/j.smallrumres.2021.106398

6. Zhu X, Wen J, Wang J. Effect of environmental temperature and humidity on milk production and milk composition of Guanzhong dairy goats. Vet Anim Sci. (2020) 9:100121. doi: 10.1016/j.vas.2020. 100121

7. Ranadheera CS, Evans CA, Baines SK, Balthazar CF, Cruz AG, Esmerino EA, et al. Probiotics in goat milk products: delivery capacity and ability to improve sensory attributes. Compr Rev Food Sci Food Saf. (2019) 18:86782. doi: 10.1111/1541-4337.12447

8. Pulina G, Milán MJ, Lavín MP, Theodoridis A, Morin E, Capote J, et al. Invited review: current production trends, farm structures, and economics of the dairy sheep and goat sectors. J Dairy Sci. (2018) 101:671529. doi: 10.3168/jds.2017-14015

9. Gámbaro A, González V, Jiménez S, Arechavaleta A, Irigaray B, Callejas N, et al. Chemical and sensory profiles of commercial goat cheeses. Int Dairy J. (2017) 69:1-8. doi: 10.1016/j.idairyj.2017.01.009

10. Turkmen N. The nutritional value and health benefits of goat milk components. In: Watson RR, Collier RJ, Preedy VR, editors. Nutrients 
in Dairy Their Implications on Health Disease. Academic Press (2017). p. 441-9. doi: 10.1016/B978-0-12-809762-5.00035-8

11. Delgadillo JA, Martin GB. Alternative methods for control of reproduction in small ruminants: a focus on the needs of grazing industries. Anim Front. (2015) 5:57-65. doi: 10.2527/af.2015-0009

12. Maroteau C, Palhière I, Larroque $H$, Clément V, Ferrand M, TosserKlopp G, et al. Genetic parameter estimation for major milk fatty acids in alpine and saanen primiparous goats. J Dairy Sci. (2014) 97:314255. doi: $10.3168 /$ jds.2013-7328

13. Sandrucci A, Bava L, Tamburini A, Gislon G, Zucali M. Management practices and milk quality in dairy goat farms in Northern Italy. Ital J Anim Sci. (2019) 18:1-12. doi: 10.1080/1828051X.2018.1466664

14. Baldin M, Dresch R, Souza J, Fernandes D, Gama MAS, Harvatine KJ, et al. CLA induced milk fat depression reduced dry matter intake and improved energy balance in dairy goats. Small Rumin Res. (2014) 116:4450. doi: 10.1016/j.smallrumres.2013.10.001

15. Kompan D, Komprej A. The effect of fatty acids in goat milk on health. In: Chaiyabutr N, editor. Milk Production - An Up-to-Date Overview of Animal Nutrition, Management and Health. London: IntechOpen (2017). doi: $10.5772 / 50769$

16. Song N, Chen Y, Luo J, Huang L, Tian H, Li C, et al. Negative regulation of $\alpha$ S1-casein (CSN1S1) improves $\beta$-casein content and reduces allergy potential in goat milk. J Dairy Sci. (2020) 103:956172. doi: $10.3168 /$ jds.2020-18595

17. Rupp R, Huau C, Caillat H, Fassier T, Bouvier F, Pampouille E, et al. Divergent selection on milk somatic cell count in goats improves udder health and milk quality with no effect on nematode resistance. J Dairy Sci. (2019) 102:5242-53. doi: $10.3168 /$ jds.2018-15664

18. Clark S, Mora García MB. A 100-year review: advances in goat milk research. J Dairy Sci. (2017) 100:10026-44. doi: 10.3168/jds.2017-13287

19. Podhorecká K, Borková M, Šulc M, Seydlová R, Dragounová H, Švejcarová $\mathrm{M}$, et al. Somatic cell count in goat milk: an indirect quality indicator. Foods. (2021) 10:1046. doi: 10.3390/foods10051046

20. Dolatowska-Zebrowska K, Ostrowska-Ligeza E, Wirkowska-Wojdyła M, Bryś J, Górska A. Characterization of thermal properties of goat milk fat and goat milk chocolate by using DSC, PDSC and TGA methods. J Therm Anal Calorim. (2019) 138:2769-2779. doi: 10.1007/s10973-019-08181-0

21. de Oliveira IK, Oliveira MM, Oliveira AT, da Silva GM, de Oliveira TA, dos Santos KM, et al. Fermentative behavior of native lactobacilli in goat milk and their survival under in vitro simulated gastrointestinal conditions. $L W T$ Food Sci Technol. (2021) 135:109905. doi: 10.1016/j.lwt.2020.109905

22. Renna M, Lussiana C, Cornale P, Fortina R, Mimosi A. Changes in goat milk fatty acids during abrupt transition from indoor to pasture diet. Small Rumin Res. (2012) 108:12-21. doi: 10.1016/j.smallrumres.2012. 06.007

23. Pajor F, Egerszegi I, Steiber O, Bodnár Á, Póti P. Effect of marine algae supplementation on the fatty acid profile of milk of dairy goats kept indoor and on pasture. J Anim Feed Sci. (2019) 28:16976. doi: $10.22358 /$ jafs $/ 109955 / 2019$

24. Morand-Fehr P, Fedele V, Decandia M, Le Frileux Y. Influence of farming and feeding systems on composition and quality of goat and sheep milk. Small Rumin Res. (2007) 68:20-34. doi: 10.1016/j.smallrumres.2006.09.019

25. Lopez A, Vasconi M, Moretti VM, Bellagamba F. Fatty acid profile in goat milk from high- and low-input conventional and organic systems. Animals. (2019) 9:452. doi: 10.3390/ani9070452

26. Boccia AC, Cusano E, Scano P, Consonni R. NMR lipid profile of milk from alpine goats with supplemented hempseed and linseed diets. Molecules. (2020) 25:1491. doi: 10.3390/molecules25 071491

27. Vieitez I, Irigaray B, Callejas N, González V, Gimenez S, Arechavaleta $\mathrm{A}$, et al. Composition of fatty acids and triglycerides in goat cheeses and study of the triglyceride composition of goat milk and cow milk blends. J Food Compos Anal. (2016) 48:95-101. doi: 10.1016/j.jfca.2016. 02.010

28. Gastaldi D, Medana C, Giancotti V, Aigotti R, Dal Bello F, Baiocchi C. HPLC-APCI analysis of triacylglycerols in milk fat from different sources. Eur J Lipid Sci Technol. (2011) 113:197-207. doi: 10.1002/ejlt. 201000068
29. Carloni M, Fedeli D, Roscioni T, Gabbianelli R, Falcioni G. Seasonal variation of fat composition in sheep's milk from areas of central Italy. Mediterr J Nutr Metab. (2010) 3:55-60. doi: 10.1007/s12349-009-0057-0

30. Domagała J, Sady M, Grega T, Pustkowiak H, Florkiewicz A. The influence of cheese type and fat extraction method on the content of conjugated linoleic acid. J Food Compos Anal. (2010) 23:238-43. doi: 10.1016/j.jfca.2009.11.002

31. Prandini A, Sigolo S, Tansini G, Brogna N, Piva G. Different level of conjugated linoleic acid (CLA) in dairy products from Italy. J Food Compos Anal. (2007) 20:472-9. doi: 10.1016/j.jfca.2007.03.001

32. Vieitez I, Callejas N, Saibene M, Cabrera L, Irigaray B, Grompone MA. Fatty acids and triglycerides composition in Uruguayan cow, sheep and goat cheeses. J Food Sci Eng. (2013) 3:379. Available online at: http://riquim.fq.ed u.uy/archive/files/249cdeba78a2a73e54129b1929440b13.pdf

33. Moatsou G, Park YW. Goat milk products: types of products, manufacturing technology, chemical composition, and marketing. In: Park YW, Haenlein GFW, and Wendorff WL, editors. Handbook of Milk of Non-Bovine Mammals. Oxford: John Wiley \& Sons, Ltd (2017). p. 84-150. doi: 10.1002/9781119110316.ch2.3

34. Ribeiro JC, Peruzi GAS, Bruzaroski SR, Tamanini R, Lobo CMO, Alexandrino B, et al. Short communication: effect of bactofugation of raw milk on counts and microbial diversity of psychrotrophs. J Dairy Sci. (2019) 102:7794-9. doi: $10.3168 /$ jds.2018-16148

35. Chen D, Li X, Zhao X, Qin Y, Wang J, Wang C. Comparative proteomics of goat milk during heated processing. Food Chem. (2019) 275:50414. doi: 10.1016/j.foodchem.2018.09.129

36. Cole S, Goetze A, Meunier-Goddik L. Pasteurized milk. In: McSweeney PLH, McNamara JP, editors. Encyclopedia of Dairy Sciences. 3rd edn. Oxford: Academic Press (2020). p. 444-50. doi: 10.1016/B978-0-12-818766-1.00142-2

37. Deeth HC. Heat treatment of milk: pasteurization (HTST) and thermization (LTLT). In: McSweeney PLH, McNamara JP, editors. Encyclopedia of Dairy Sciences. 3rd Edn. Oxford: Academic Press (2020). p. 64554. doi: 10.1016/B978-0-12-818766-1.00133-1

38. Botta L, Bechan R, Yilmaz A, Di Bartolomeo R. Prosthetic valve endocarditis due to brucella: successful outcome with a combined strategy. J Cardiovasc Med. (2009) 10:257-8. doi: 10.2459/JCM.0b013e32831ec369

39. Calvo MV, Juárez $M$, Fontecha J. Cream manufacture. In: McSweeney PLH, McNamara JP, editors. Encyclopedia of Dairy Sciences. 3rd Edn. Oxford: Academic Press (2020). p. 396-404. doi: 10.1016/B978-0-12-818766-1.00172-0

40. Park YW, Guo M. Goat milk products: types of products, manufacturing technology, chemical composition, and marketing. In: Park YW, Haenlein GFW, editors. Handbook of Milk of Non-Bovine Mammals. Oxford: John Wiley \& Sons, Ltd (2006). p. 59-106. doi: 10.1002/9780470999738.ch4

41. Paschino P, Stocco G, Dettori ML, Pazzola M, Marongiu ML, Pilo CE, et al. Characterization of milk composition, coagulation properties, and cheese-making ability of goats reared in extensive farms. J Dairy Sci. (2020) 103:5830-5843. doi: 10.3168/jds.2019-17805

42. Medina $M$, Nuñez $M$. Cheeses from ewe and goat milk. In: McSweeney PLH, Fox PF, Cotter PD, Everett DW, editors. Cheese. 4th edn. San Diego, CA: Academic Press (2017). p. 1069-91. doi: 10.1016/B978-0-12-417012-4.00041-7

43. do Oriente SF, Barreto F, Tomaszewski CA, Barnet LS, Souza NC, Oliveira HML, et al. Retention of vitamin A after goat milk processing into cheese: a nutritional strategy. J Food Sci Technol. (2020) 57:436470. doi: 10.1007/s13197-020-04473-8

44. Amigo L, Fontecha J. Goat milk. In: McSweeney PLH, McNamara JP, editors. Encyclopedia of Dairy Sciences. 3rd Edn. Oxford: Academic Press. (2020). p. 797-808. doi: 10.1016/B978-0-12-818766-1.00126-4

45. Pappa EC, Kondyli E, Bosnea L, Malamou E, Vlachou A-M. Chemical, microbiological, sensory, and rheological properties of fresh goat milk cheese made by different starter cultures during storage. J Food Process Eng. (2021) e13788. doi: 10.1111/jfpe.13788

46. Calvo MV, Castillo I, Díaz-Barcos V, Requena T, Fontecha J. Effect of a hygienized rennet paste and a defined strain starter on proteolysis, texture and sensory properties of semi-hard goat cheese. Food Chem. (2007) 102:917-24. doi: 10.1016/j.foodchem.2006. 06.028 
47. Tabet E, Mangia NP, Mouannes E, Hassoun G, Helal Z, Deiana P. Characterization of goat milk from Lebanese Baladi breed and his suitability for setting up a ripened cheese using a selected starter culture. Small Rumin Res. (2016) 140:13-7. doi: 10.1016/j.smallrumres.2016.05.011

48. Lima MJR, Teixeira-Lemos E, Oliveira J, P.Teixeira-Lemos L, Monteiro AMC, Costa JM. Nutritional and health profile of goat products: focus on health benefits of goat milk. In: Kukovics S, editor. Goat Science. London: IntechOpen (2017). doi: 10.5772/intechopen.70321

49. Hartmann K, Berthier F, Licitra G. Acid-Coagulated cheeses. In: Papademas P, Bintsis T, editors. Global Cheesemaking Technology. Oxford: John Wiley \& Sons, Ltd (2018). p. 436-45. doi: 10.1002/9781119046165.ch12

50. Deshwal GK, Ameta R, Sharma H, Singh AK, Panjagari NR, Baria B. Effect of ultrafiltration and fat content on chemical, functional, textural and sensory characteristics of goat milk-based Halloumi type cheese. LWT. (2020) 126:109341. doi: 10.1016/j.lwt.2020.109341

51. Argenta AB, De Lima JJ, Nogueira A, Scheer ADP. Evaluation of concentration process of bovine, goat and buffalo whey proteins by ultrafiltration. J Food Sci Technol. (2021) 58:166372. doi: 10.1007/s13197-020-04675-0

52. Skeie SB. Quality aspects of goat milk for cheese production in Norway: a review. Small Rumin Res. (2014) 122:107. doi: 10.1016/j.smallrumres.2014.07.012

53. Miocinovic J, Miloradovic Z, Josipovic M, Nedeljkovic A, Radovanovic M, Pudja P. Rheological and textural properties of goat and cow milk set type yoghurts. Int Dairy J. (2016) 58:43-5. doi: 10.1016/j.idairyj.2015.11.006

54. Jia R, Chen H, Chen H, Ding W. Effects of fermentation with Lactobacillus rhamnosus GG on product quality and fatty acids of goat milk yogurt. J Dairy Sci. (2016) 99:221-7. doi: 10.3168/jds.2015-10114

55. Sumarmono J, Sulistyowati M, Soenarto. Fatty acids profiles of fresh milk, yogurt and concentrated yogurt from peranakan etawah goat milk. Procedia Food Sci. (2015) 3:216-22. doi: 10.1016/j.profoo.2015.01.024

56. Feng C, Wang B, Zhao A, Wei L, Shao Y, Wang Y, et al. Quality characteristics and antioxidant activities of goat milk yogurt with added jujube pulp. Food Chem. (2019) 277:238-45. doi: 10.1016/j.foodchem.2018.10.104

57. Aadil RM, Zeng X-A, Sun D-W, Wang M-S, Liu Z-W, Zhang Z-H. Combined effects of sonication and pulsed electric field on selected quality parameters of grapefruit juice. LWT Food Sci Technol. (2015) 62:8903. doi: 10.1016/j.lwt.2014.10.025

58. Zhang Y, Munir MT, Udugama I, Yu W, Young BR. Modelling of a milk powder falling film evaporator for predicting process trends and comparison of energy consumption. J Food Eng. (2018) 225:2633. doi: 10.1016/j.jfoodeng.2018.01.016

59. Nascimento A, Cavalcanti-Mata MERM, Martins Duarte ME, Pasquali M, Lisboa HM. Construction of a design space for goat milk powder production using moisture sorption isotherms. J Food Process Eng. (2019) 42:e13228. doi: 10.1111/jfpe.13228

60. Nieuwenhuijse H. "Evaporated milk. In: McSweeney PLH, McNamara JP, editors. Encyclopedia of Dairy Sciences. 3rd Edn. Oxford: Academic Press (2011). p. 525-31. doi: 10.1016/B978-0-12-818766-1.00350-0

61. Karthik P, Chhanwal N, Anandharamakrishnan C. Drum drying. In: Anandharamakrishnan C, editor. Handbook of Drying for Dairy Products. Oxford: John Wiley \& Sons, Ltd (2017). p. 43-56. doi: 10.1002/9781118930526.ch4

62. Xing X, Zhang $\mathrm{Y}$, Wu Q, Wang X, Ge W, Wu C. Prevalence and characterization of Staphylococcus aureus isolated from goat milk powder processing plants. Food Control. (2016) 59:644-650. doi: 10.1016/j.foodcont.2015.06.042

63. Marques de Almeida M, Haenlein GFW. Goat milk. In: Park YW, Haenlein GFW, Wendorff WL, editors. Handbook of Milk of NonBovine Mammals. Oxford: John Wiley \& Sons, Ltd (2017). p. 1141. doi: 10.1002/9781119110316.ch2

64. Ribeiro AC, Ribeiro SDA. Specialty products made from goat milk. Small Rumin Res. (2010) 89:225-33. doi: 10.1016/j.smallrumres.2009.12.048

65. Samardžija D, Zamberlin Š, Pogačić T. Psychrotrophic bacteria and milk and dairy products quality. Mljekarsivo. (2012) 62:77-95. Available online at: https://hrcak.srce.hr/file/124020

66. Tan SF, Chin NL, Tee TP, Chooi SK. Physico-Chemical changes, microbiological properties, and storage shelf life of cow and goat milk from industrial high-pressure processing. Processes. (2020) 8:697. doi: 10.3390/pr8060697

67. Hovjecki M, Miloradovic Z, Rac V, Pudja P, Miocinovic J. Influence of heat treatment of goat milk on casein micelle size, rheological and textural properties of acid gels and set type yoghurts. J Texture Stud. (2020) 51:6807. doi: $10.1111 /$ jtxs. 12524

68. Pestana J, Gennari A, Monteiro B, Lehn D, Souza C. Effects of pasteurization and ultra-high temperature processes on proximate composition and fatty acid profile in bovine milk. Am J Food Technol. (2015) 10:26572. doi: 10.3923/ajft.2015.265.272

69. Chen BY, Grandison AS, Lewis MJ. Comparison of heat stability of goat milk subjected to ultra-high temperature and in-container sterilization. J Dairy Sci. (2012) 95:1057-63. doi: 10.3168/jds.2011-4367

70. Prasantha BDR, Wimalasiri KMS. Effect of HTST thermal treatments on end-use quality characteristics of goat milk. Int J Food Sci. (2019) 2019:e1801724. doi: 10.1155/2019/1801724

71. Deeth HC. The effect of UHT processing and storage on milk proteins. In: Boland M, Singh H, editors. Milk Proteins. 3rd Edn. London: Academic Press (2020). p. 385-421. doi: 10.1016/B978-0-12-815251-5.00010-4

72. Deshwal GK, Tiwari S, Kadyan S. Applications of emerging processing technologies for quality and safety enhancement of nonbovine milk and milk products. LWT Food Sci Technol. (2021) 149:111845. doi: 10.1016/j.lwt.2021.111845

73. Fonseca CR, Bordin K, Fernandes AM, Rodrigues CEC, Corassin CH, Cruz AG, et al. Storage of refrigerated raw goat milk affecting the quality of whole milk powder. J Dairy Sci. (2013) 96:4716-24. doi: 10.3168/jds.2012-6120

74. Gengatharan A, Dykes GA, Choo WS. Stability of betacyanin from red pitahaya (Hylocereus polyrhizus) and its potential application as a natural colourant in milk. Int J Food Sci Technol. (2016) 51:42734. doi: 10.1111/ijfs.12999

75. Rahimah S, Malinda W, Zaida, Sukri N, Salma JK, Tallei TE, et al. Betacyanin as bioindicator using time-temperature integrator for smart packaging of fresh goat milk. Sci World J. (2020) 2020:e4303140. doi: 10.1155/2020/4303140

76. Delgado KF, Frasao BS, Costa MP, Conte-Junior C. Different alternatives to improve rheological and textural characteristics of fermented goat productsA review. Rheol Open Access. (2017) 1:1-6. Available online at: https://www. omicsonline.org/open-access/different-alternatives-to-improve-rheologicaland-textural-characteristicsof-fermented-goat-products--a-review.php?aid= 87482

77. García V, Rovira S, Boutoial K, López MB. Improvements in goat milk quality: a review. Small Rumin Res. (2014) 121:51-7. doi: 10.1016/j.smallrumres.2013.12.034

78. Juan B, Zamora A, Quevedo JM, Trujillo A-J. Proteolysis of cheese made from goat milk treated by ultra high pressure homogenisation. LWT Food Sci Technol. (2016) 69:17-23. doi: 10.1016/j.lwt.2015.12.013

79. Oliveira MM de, Augusto PED, Cruz AG da, Cristianini M. Effect of dynamic high pressure on milk fermentation kinetics and rheological properties of probiotic fermented milk. Innov Food Sci Emerg Technol. (2014) 26:6775. doi: 10.1016/j.ifset.2014.05.013

80. Huppertz T. Novel technologies for dairy processing: applications for non-cow milk. In: Tsakalidou E, Papadimitriou K, editors. Non-Bovine Milk Products. San Diego, CA: Academic Press (2016). 187-208. doi: 10.1016/B978-0-12-803361-6.00008-9

81. Razali MF, Narayanan S, Md. Hazmi NA, Abdul Karim Shah NN, Mustapa Kamal SM, Mohd Fauzi NA, et al. Minimal processing for goat milk preservation: effect of high-pressure processing on its quality. J Food Process Preserv. (2021) 45:e15590. doi: 10.1111/jfpp. 15590

82. Almanza-Rubio JL, Gutiérrez-Méndez N, Leal-Ramos MY, Sepulveda D, Salmeron I. Modification of the textural and rheological properties of cream cheese using thermosonicated milk. J Food Eng. (2016) 168:22330. doi: 10.1016/j.jfoodeng.2015.08.002

83. Ragab ES, Zhang S, Pang X, Lu J, Nassar KS, Yang B, et al. Ultrasound improves the rheological properties and microstructure of rennet-induced gel from goat milk. Int Dairy J. (2020) 104:104642. doi: 10.1016/j.idairyj.2020.104642

84. Delgado K, Vieira C, Dammak I, Frasão B, Brígida A, Costa M, et al. Different ultrasound exposure times influence the physicochemical and 
microbial quality properties in probiotic goat milk yogurt. Molecules. (2020) 25:4638. doi: $10.3390 /$ molecules 25204638

85. Agarwal S, Beausire RLW, Patel S, Patel H. Innovative uses of milk protein concentrates in product development. J Food Sci. (2015) 80:A239. doi: 10.1111/1750-3841.12807

86. Chon K, Kim SJ, Moon J, Cho J. Combined coagulation-disk filtration process as a pretreatment of ultrafiltration and reverse osmosis membrane for wastewater reclamation: an autopsy study of a pilot plant. Water Res. (2012) 46:1803-16. doi: 10.1016/j.watres.2011.12.062

87. Kumar P, Sharma N, Ranjan R, Kumar S, Bhat ZF, Jeong DK. Perspective of membrane technology in dairy industry: a review. Asian-Australas J Anim Sci. (2013) 26:1347-58. doi: 10.5713/ajas.2013.13082

88. Vieira AH, Balthazar CF, Guimaraes JT, Rocha RS, Pagani MM, Esmerino EA, et al. Advantages of microfiltration processing of goat whey orange juice beverage. Food Res Int. (2020) 132:109060. doi: 10.1016/j.foodres.2020.109060

89. Ahmad T, Butt MZ, Aadil RM, Inam-ur-Raheem M, Abdullah, Bekhit AE-D, et al. Impact of nonthermal processing on different milk enzymes. Int J Dairy Technol. (2019) 72:481-95. doi: 10.1111/1471-0307.12622

90. Pankiewicz U, Góral M, Kozłowicz K, Góral D. Novel method of zinc ions supplementing with fermented and unfermented ice cream with using PEF. Int J Food Sci Technol. (2019) 54:2035-44. doi: 10.1111/ijfs.14103

91. Zhang Z-H, Wang L-H, Zeng X-A, Han Z, Brennan CS. Non-thermal technologies and its current and future application in the food industry: a review. Int J Food Sci Technol. (2019) 54:1-13. doi: 10.1111/ijfs.13903

92. Mohamad A, Shah NNAK, Sulaiman A, Adzahan NM, Aadil RM. Impact of the pulsed electric field on physicochemical properties, fatty acid profiling, and metal migration of goat milk. J Food Process Preserv. (2020) 44:e14940. doi: 10.1111/jfpp.14940

93. Hodgkinson AJ, Wallace OAM, Boggs I, Broadhurst M, Prosser CG. Gastric digestion of cow and goat milk: impact of infant and young child in vitro digestion conditions. Food Chem. (2018) 245:275-81. doi: 10.1016/j.foodchem.2017.10.028

94. Prosser CG. Compositional and functional characteristics of goat milk and relevance as a base for infant formula. J Food Sci. (2021) 86:25765. doi: 10.1111/1750-3841.15574

95. Lou X, Li J, Zhang X, Wang J, Wang C. Variations in fatty acid composition of laoshan goat milk from partum to 135 days postpartum. Anim Sci J. (2018) 89:1628-38. doi: 10.1111/asj.13098

96. Sun Y, Wang C, Sun X, Guo M. Protein digestion properties of Xinong Saanen goat colostrum and mature milk using in vitro digestion model. $J$ Sci Food Agric. (2019) 99:5819-25. doi: 10.1002/jsfa.9852

97. Li Y, Chen D, Li J, Zhang X-X, Wang C-F, Wang J-M. Changes in superoxide dismutase activity postpartum from Laoshan goat milk and factors influencing its stability during processing. Ital J Anim Sci. (2018) 17:835-44. doi: 10.1080/1828051X.2018.1448306

98. Parc AL, Dallas DC, Duaut S, Leonil J, Martin P, Barile D. Characterization of goat milk lactoferrin $\mathrm{N}$-glycans and comparison with the N-glycomes of human and bovine milk. Electrophoresis. (2014) 35:1560-70. doi: 10.1002/elps.201300619

99. Rubin M, Modai S, Rayman S, Kaplan KM, Mendelson E, Lichtenberg D. Antiviral properties of goat milk. Clin Nutr Open Sci. (2021) 37:111. doi: 10.1016/j.nutos.2021.03.002

100. Gong H, Gao J, Wang Y, Luo QW, Guo KR, Ren FZ, et al. Identification of novel peptides from goat milk casein that ameliorate high-glucoseinduced insulin resistance in HepG2 cells. J Dairy Sci. (2020) 103:490718. doi: $10.3168 /$ jds.2019-17513

101. Ibrahim HR, Ahmed AS, Miyata T. Novel angiotensin-converting enzyme inhibitory peptides from caseins and whey proteins of goat milk. J Adv Res. (2017) 8:63-71. doi: 10.1016/j.jare.2016.12.002

102. Park YW. Bioactive components in goat milk. In: Park YW, editor. Bioactive Components in Milk and Dairy Products. Oxford: John Wiley \& Sons, Ltd (2009). p. 43-81. doi: 10.1002/9780813821504.ch3

103. Meisel H, FitzGerald RJ. Biofunctional peptides from milk proteins: mineral binding and cytomodulatory effects. Curr Pharm Des. (2003) 9:1289-95. doi: 10.2174/13816120334 54847
104. Park YW, Haenlein GFW. Therapeutic, hypo-allergenic and bioactive potentials of goat milk, and manifestations of food allergy. In: Park YW, Haenlein GFW, Wendorff WL, editors. Handbook of Milk of NonBovine Mammals. Oxford: John Wiley \& Sons, Ltd (2017). p. 15179. doi: 10.1002/9781119110316.ch2.4

105. Cakir B, Tunali-Akbay T. Potential anticarcinogenic effect of goat milkderived bioactive peptides on HCT-116 human colorectal carcinoma cell line. Anal Biochem. (2021) 622:114166. doi: 10.1016/j.ab.2021.114166

106. Giraldo J, Althaus RL, Beltrán MC, Molina MP. Antimicrobial activity in cheese whey as an indicator of antibiotic drug transfer from goat milk. Int Dairy J. (2017) 69:40-4. doi: 10.1016/j.idairyj.2017.02.003

107. Niaz B, Saeed F, Ahmed A, Imran M, Maan AA, Khan MKI, et al. Lactoferrin (LF): a natural antimicrobial protein. Int J Food Prop. (2019) 22:162641. doi: 10.1080/10942912.2019.1666137

108. Park YW, Haenlein GFW. Therapeutic and hypoallergenic values of goat milk and implication of food allergy. In: Handbook of Milk of Non-Bovine Mammals. John Wiley \& Sons, Ltd (2008). p. 12135. doi: 10.1002/9780470999738.ch6

109. Raynal-Ljutovac K, Lagriffoul G, Paccard P, Guillet I, Chilliard Y. Composition of goat and sheep milk products: an update. Small Rumin Res. (2008) 79:57-72. doi: 10.1016/j.smallrumres.2008.07.009

110. Lara-Villoslada F, Debras E, Nieto A, Concha A, Gálvez J, López-Huertas $\mathrm{E}$, et al. Oligosaccharides isolated from goat milk reduce intestinal inflammation in a rat model of dextran sodium sulfate-induced colitis. Clin Nutr. (2006) 25:477-88. doi: 10.1016/j.clnu.2005.11.004

111. Meyrand M, Dallas DC, Caillat H, Bouvier F, Martin P, Barile D. Comparison of milk oligosaccharides between goats with and without the genetic ability to synthesize as1-casein. Small Rumin Res. (2013) 113:41120. doi: 10.1016/j.smallrumres.2013.03.014

112. Kunz C, Rudloff S. Health promoting aspects of milk oligosaccharides. Int Dairy J. (2006) 16:1341-6. doi: 10.1016/j.idairyj.2006.06.020

113. Alférez MJM, López-Aliaga I, Nestares T, Díaz-Castro J, Barrionuevo M, Ros $\mathrm{PB}$, et al. Dietary goat milk improves iron bioavailability in rats with induced ferropenic anaemia in comparison with cow milk. Int Dairy J. (2006) 16:813-21. doi: 10.1016/j.idairyj.2005.08.001

114. Alférez MJM, López Aliaga I, Barrionuevo M, Campos MS. Effect of dietary inclusion of goat milk on the bioavailability of zinc and selenium in rats. $J$ Dairy Res. (2003) 70:181-7. doi: 10.1017/S0022029903006058

115. Barrionuevo M, López Aliaga I, Alférez MJM, Mesa E, Nestáres T, Campos MS. Beneficial effect of goat milk on bioavailability of copper, zinc and selenium in rats. J Physiol Biochem. (2003) 59:1118. doi: $10.1007 / \mathrm{BF} 03179876$

116. Panchal G, Hati S, Sakure A. Characterization and production of novel antioxidative peptides derived from fermented goat milk by L. fermentum. LWT Food Sci Technol. (2020) 119:108887. doi: 10.1016/j.lwt.2019.108887

117. Grant C, Rotherham B, Sharpe S, Scragg R, Thompson J, Andrews J, et al. Randomized, double-blind comparison of growth in infants receiving goat milk formula versus cow milk infant formula. J Paediatr Child Health. (2005) 41:564-8. doi: 10.1111/j.1440-1754.2005.00722.x

118. López-Aliaga I, Alférez MJM, Nestares MT, Ros PB, Barrionuevo M, Campos MS. Goat milk feeding causes an increase in biliary secretion of cholesterol and a decrease in plasma cholesterol levels in rats. J Dairy Sci. (2005) 88:1024-30. doi: 10.3168/jds.S0022-0302(05)72770-3

119. Amati L, Marzulli G, Martulli M, Tafaro A, Jirillo F, Pugliese V, et al. Donkey and goat milk intake and modulation of the human aged immune response. Curr Pharm Des. (2010) 16:864-9. doi: 10.2174/138161210790883651

120. Tripathi MK. Comforts in quality and production of goat milk. Adv Dairy Res. (2015) 3:1-2. Available online at: https://www.longdom.org/open-acces s/comforts-in-quality-and-production-of-goat-milk-2329-888X-1000e115.p df

121. Kalyan S, Meena S, Kapila S, Sowmya K, Kumar R. Evaluation of goat milk fat and goat milk casein fraction for anti-hypercholesterolaemic and antioxidative properties in hypercholesterolaemic rats. Int Dairy J. (2018) 84:23-7. doi: 10.1016/j.idairyj.2018.03.012

122. Zervas G, Tsiplakou E. Goat milk. In: Milk and Dairy Products in Human Nutrition. John Wiley \& Sons, Ltd (2013). p. 498-518. doi: 10.1002/9781118534168.ch23 
123. Shori AB. The potential applications of probiotics on dairy and non-dairy foods focusing on viability during storage. Biocatal Agric Biotechnol. (2015) 4:423-31. doi: 10.1016/j.bcab.2015.09.010

124. Hua C, Ma Q, Zhu Y, Xia S, Liu Z, Li L, et al. Repurposing of a clinically used anti-HPV agent to prevent and treat SARS-CoV-2 infection as an intranasal formulation. Signal Transduct Target Ther. (2021) 6:13. doi: 10.1038/s41392-021-00737-7

125. Kocak A, Sanli T, Anli EA, Hayaloglu AA. Role of using adjunct cultures in release of bioactive peptides in white-brined goat-milk cheese. LWT Food Sci Technol. (2020) 123:109127. doi: 10.1016/j.lwt.2020.109127

126. Yilmaz-Ersan L, Ozcan T, akpinar A, Sahin S. The antioxidative capacity of kefir produced from goat milk. Int J Chem Eng Appl. (2016) 7:226. doi: 10.7763/IJCEA.2016.V7.535

127. Medeiros GKVV, Queiroga RCRE, Costa WKA, Gadelha CAA, Lacerda RR, Lacerda JTJG, et al. Proteomic of goat milk whey and its bacteriostatic and antitumour potential. Int J Biol Macromol. (2018) 113:11623. doi: 10.1016/j.ijbiomac.2018.01.200

128. Assis POA de, Guerra GCB, Araújo DF de S, Araújo Júnior RF de, Machado TADG, Araújo AA de, et al. Intestinal anti-inflammatory activity of goat milk and goat yoghurt in the acetic acid model of rat colitis. Int Dairy J. (2016) 56:45-54. doi: 10.1016/j.idairyj.2015.11.002

129. Tsorotioti SE, Nasopoulou C, Detopoulou M, Sioriki E, Demopoulos CA, Zabetakis I. In vitro anti-atherogenic properties of traditional greek cheese lipid fractions. Dairy Sci Technol. (2014) 94:269-81. doi: 10.1007/s13594-014-0161-x

130. Nasopoulou C, Smith T, Detopoulou M, Tsikrika C, Papaharisis L, Barkas D, et al. Structural elucidation of olive pomace fed sea bass (Dicentrarchus labrax) polar lipids with cardioprotective activities.
Food Chem. (2014) 145:1097-105. doi: 10.1016/j.foodchem.2013. 08.091

131. Poutzalis S, Anastasiadou A, Nasopoulou C, Megalemou K, Sioriki E, Zabetakis I. Evaluation of the in vitro anti-atherogenic activities of goat milk and goat dairy products. Dairy Sci Technol. (2016) 96:317327. doi: 10.1007/s13594-015-0266-x

132. Gallier S, Tolenaars L, Prosser C. whole goat milk as a source of fat and milk fat globule membrane in infant formula. Nutrients. (2020) 12:3486. doi: 10.3390/nu12113486

Conflict of Interest: The authors declare that the research was conducted in the absence of any commercial or financial relationships that could be construed as a potential conflict of interest.

Publisher's Note: All claims expressed in this article are solely those of the authors and do not necessarily represent those of their affiliated organizations, or those of the publisher, the editors and the reviewers. Any product that may be evaluated in this article, or claim that may be made by its manufacturer, is not guaranteed or endorsed by the publisher.

Copyright (c) 2021 Nayik, Jagdale, Gaikwad, Devkatte, Dar, Dezmirean, Bobis, Ranjha, Ansari, Hemeg and Alotaibi. This is an open-access article distributed under the terms of the Creative Commons Attribution License (CC BY). The use, distribution or reproduction in other forums is permitted, provided the original author(s) and the copyright owner(s) are credited and that the original publication in this journal is cited, in accordance with accepted academic practice. No use, distribution or reproduction is permitted which does not comply with these terms. 